West African Papers

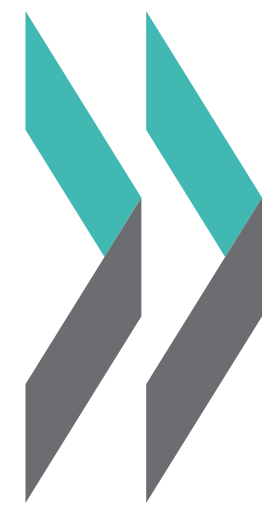

\title{
Businesses and Health in Border Cities
}

APRIL 2019 NO. 22

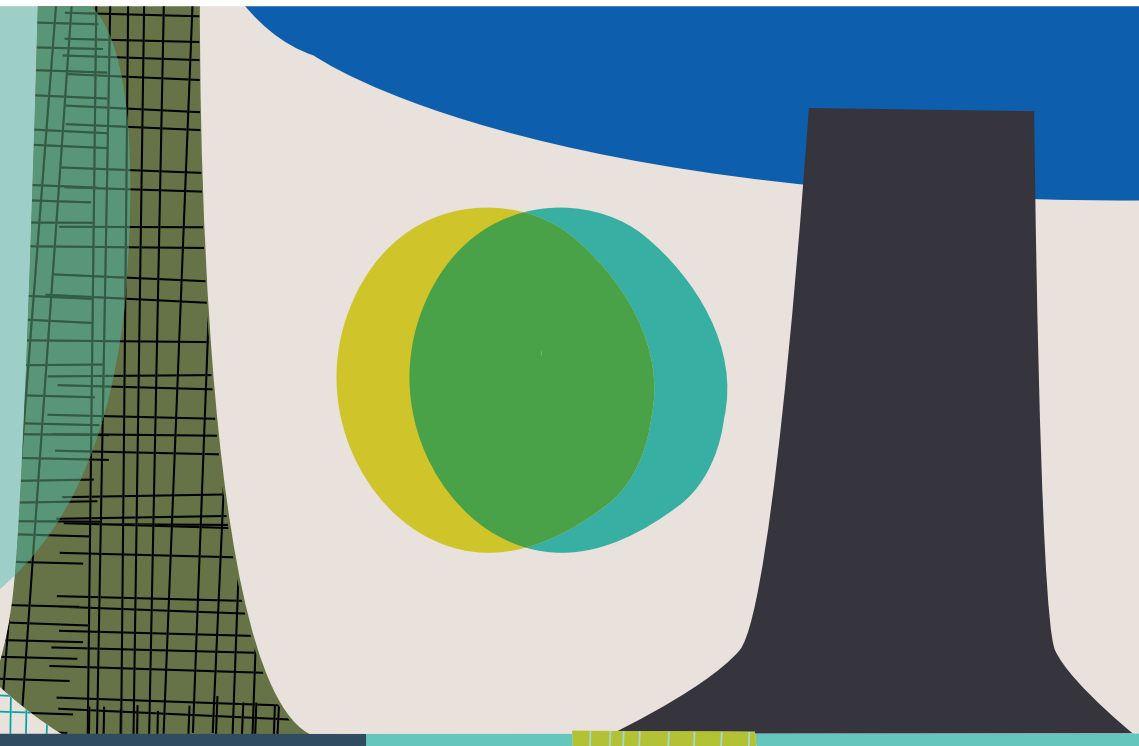





\section{BUSINESSES AND HEALTH IN BORDER CITIES \\ "Cities" Collection}

Under the direction of Marie Trémolières and Olivier J. Walther

\section{Also in this Collection:}

"Regional Integration in Border Cities", No. 20

"Population and Morphology of Border Cities", No. 21

"Accessibility and Infrastructure in Border Cities", No. 23 


\section{WEST AFRICAN PAPERS}

The West African Papers explore African socio-economic, political and security dynamics from a regional and multidisciplinary perspective. They seek to stimulate discussion and gather information to better anticipate the changes that will shape future policies. The series is designed for a wide audience of specialists, development practitioners, decision makers and the informed public. Papers are available in English and/or French, and summaries are available in both languages. Initiated by the Sahel and West Africa Club (SWAC) to highlight and promote West African issues, the work presented is prepared by its Secretariat, Members and partners, other OECD departments, related international organisations, associated experts and researchers.

Please cite this publication as:

OECD/SWAC (2019), "Businesses and Health in Border Cities",

West African Papers, No. 22, OECD Publishing, Paris.

https://doi.org/10.1787/6721f08d-en

ISSN 2414-2026

This paper is published under the responsibility of the Secretary-General of the OECD. The opinions expressed and the arguments employed herein do not necessarily reflect the official views of OECD member countries.

This document and any map included herein are without prejudice to the status of or sovereignty over any territory, to the delimitation of international frontiers and boundaries and to the name of any territory, city or area.

Authorised for publication by Laurent Bossard, Director, Sahel and West Africa Club Secretariat (SWAC/OECD).

You can copy, download or print OECD content for your own use, and you can include excerpts from OECD publications, databases and multimedia products in your own documents, presentations, blogs, websites and teaching materials, provided that suitable acknowledgment of OECD as source and copyright owner is given. All requests for commercial use and translation rights should be submitted to rights@oecd.org. 


\begin{abstract}
This report, part of the "Cities" collection, analyses the spatial distribution of formal enterprises and health infrastructure in West Africa. The analysis shows that sectors crucial for regional integration are concentrated in economic capitals rather than in border areas. These results illustrate the difficulty that many West African countries have in distributing the potential for economic development throughout the country. The mapping of health infrastructure shows that border towns have a surplus of medical centres and a deficit of hospitals and maternity wards relative to their urban populations. The report identifies several regions in which closer co-operation could favour the establishment of cross-border health facilities.
\end{abstract}

Key words: businesses, national cohesion, regional integration, cross-border co-operation, health JEL classification: O18, O21, 115, F15, F10

\title{
About the collection
}

One of the most dramatic transformations taking place in Africa, urbanisation is the result of growing demographics and societal and economic changes. Its dynamics and impacts need to be identified, mapped, measured and planned for in order to build sustainable policy options. This is the purpose of the "Cities" collection.

\section{The Sahel and West Africa Club}

The Sahel and West Africa Club (SWAC) is an independent, international platform. Its Secretariat is hosted at the Organisation for Economic Co-operation and Development (OECD). Its mission is to promote regional policies that will improve the economic and social well-being of people in the Sahel and West Africa. Its objectives are to improve the regional governance of food and nutrition security and improve the understanding of ongoing transformations in the region and their policy implications through regional, spatial and forward-looking analyses. SWAC Members and partners are Austria, Belgium, Canada, CILSS, the ECOWAS Commission, the European Commission, France, Luxembourg, the Netherlands, Norway, Switzerland, the UEMOA Commission and the United States. SWAC has memorandums of understanding with the NEPAD Agency and the University of Florida (Sahel Research Group).

More information: www.oecd.org/swac 


\section{The team and acknowledgments}

The editorial and drafting team at the SWAC/OECD Secretariat includes: Marie Trémolières, Executive Director, marie.tremolieres@oecd.org With the help of: Lia Beyeler, Freerk Boedeltje and Sylvie Letassey

Graphic design: Grand Krü Berlin/Daniel Krüger, daniel@grandkrue.de, and Martin Rümmele (maps)

This work is carried out under the memorandum of understanding with the University of Florida (Sahel Research Group).

Scientific direction, field co-ordination, mapping and drafting were provided by Dr Olivier J. Walther. Ph.D. Dr Walther is a visiting associate professor at the Center for African Studies at the University of Florida, associate professor of political science at the University of Southern Denmark and consultant for SWAC/OECD. owalther@ufl.edu

\section{External contributors:}

Hye Ryeon Jang, Ph.D. candidate at the Department of Political Science of the University of Florida. hrjang52@ufl.edu

Michiel van Eupen, expert in spatial modeling, researcher at the Alterra Research Institute (Wageningen University). michiel.vaneupen@wur.nl

Lawali Dambo, professor and researcher at the Department of Geography, Abdou Moumouni University of Niamey (Niger). lawali.dambo@gmail.com

The team thanks the following for their contribution to the writing of this report: Laurent Bossard, Philipp Heinrigs, SWAC/OECD Secretariat; Paul Nugent, Isabella Soi, Wolfgang Zeller, University of Edinburgh; Dieudonné Kam, Brahima Cissé, CILSS; Younsa Yansambou Habibatou, REACH; Edmond Sougué; Mohamadou Abdoul, Mamoudou Tapily, German Corporation for International Cooperation (GIZ);

Amadou Oumarou, Moustapha Koné, University of Niamey; Jade Siu, University of Birmingham; Laure Dumolard, World Health Organization; Moussa Ismaïla Touré, Binta Diakité, Agency for the Promotion of Investments in Mali; Sarah McKune, Leonardo A. Villalón, Greg Kiker, Alioune Sow, University of Florida; Bruce Whitehouse, Lehigh University; Armelle Choplin, University of Paris-Est; Christine Stabell Benn, University of Southern Denmark; Denis Retaillé, University of Bordeaux; Jean Rubio, Alexandra Lafont, Petia Tzvetanova, Jean Peyrony, Transfrontier Operational Mission (MOT). 
Table of contents

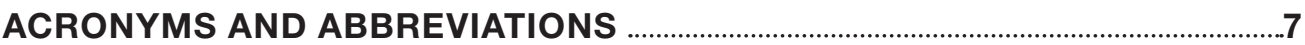

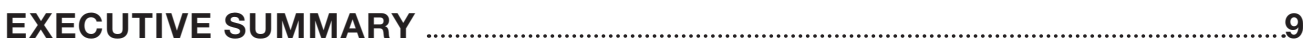

BUSINESSES, NATIONAL COHESION AND REGIONAL INTEGRATION …....12

The geography of formal businesses in West Africa ..........................................12

Business sectors and regional integration.................................................................14

Most businesses are clustered in capital cities ........................................................17

Few formal businesses present in border cities.........................................................19

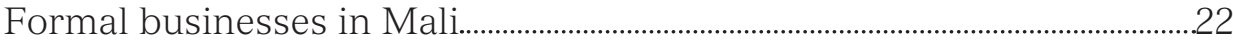

Disparities and national cohesion...................................................................................28

CITIES AND CROSS-BORDER HEALTH CO-OPERATION

IN WEST AFRICA

Medical progress and infranational disparities......................................................31

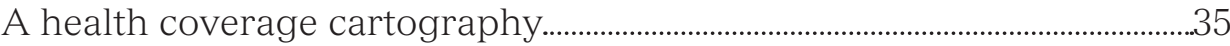

Eight out of ten health facilities are located in Nigeria........................................36

Fewer health facilities in border areas....................................................................39

Health coverage in the SKBo area

Border cities central to health co-operation........................................................47

REFERENCES

FIGURES

Figure 1.1 Percentage of GDP attributed to the informal economy, 2010-14

Figure 1.2 Percentage of formal businesses active in the process of regional integration present in economic capitals, 2016

Figure 1.3 Number of formal businesses active in the process of regional integration at a given distance from a border, 2016

Figure 1.4 Gender of Mali's business owners based on 28

Figure 2.1 Per-country density of health facilities, 2017 .38

Figure 2.2 Establishments by type and distance from a border, 2017 
Figure 2.3 Percentage of health establishments and urban population in relation to distance from a border.

\section{MAPS}

Map 1.1 Formal businesses active in the process of regional integration per city, 2016. 21

Map 1.2 Distribution of formal businesses in Mali's cities, 2016.......23

Map 1.3 Distribution of businesses per sector in the Bamako urban area, 2016 26

Map 2.1 Stunting in children under the age of five, 2000.......................32

Map 2.2 Stunting in children under the age of five, 2015.......................33

Map 2.3 Mortality rate for children under the age of five, 2000.........34

Map 2.4 Mortality rate for children under the age of five, 2015.........35

Map 2.5 Regional health coverage by type of facility, 2017...................41

Map 2.6 Health facilities in Nigeria, 2017..........................................................43

Map 2.7 Ouarokuy-Wanian cross-border health centre..........................45

Map 2.8 Population densities in Burkina Faso, Côte d'Ivoire and Mali, 2014...............................................................................................4 49

Map 2.9 Health facilities in Mali and Côte d'Ivoire, 2017.......................50

Map 2.10 Senegambia's health facilities and population base...............53

Map 2.11 Health facilities and population base in the western Gulf of Guinea.. .55

Map 2.12 Health facilities and population base between Togo

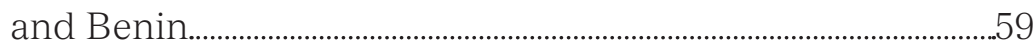

Map 2.13 Health facilities and population base in Nigeria.....................61

\section{TABLES}

Table 1.1 Number of formal businesses and quality of data per country and type, 2016

Table 1.2 Number of formal businesses per country and per sector, 2016 .. 16

Table 1.3 Cities with the highest number of businesses active in the process of regional integration, based on distance from a border, 2016.

Table 1.4 Businesses by sector and municipality, 2016. 24

Table 1.5 The ten activities in which women have the highest and lowest levels of representation in Mali, 2016. 25

Table 2.1 Number of health establishments per country and type, 2017 


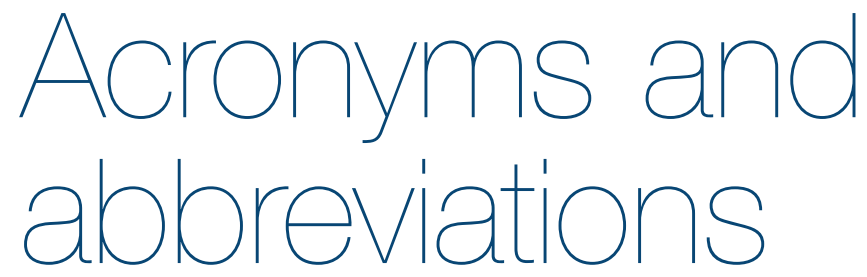
AUBP
African Union Border Programme
LCCG
Local cross-border co-operation group
PIDA
Programme for Infrastructure Development in Africa
PCTL
Programme for Local Cross-Border Co-operation
SATI
Integrated cross-border management schemes
SKBo
Sikasso-Korhogo-Bobo-Dioulasso region
UEMOA
West African Economic and Monetary Union
UNCDF United Nations Capital Development Fund
WHO
World Health Organization

This Note is based on the Africapolis database produced by SWAC. The data are based on a spatial approach and apply physical (a continuously built-up area) and demographic criterion (more than 10000 inhabitants) to define an urban agglomeration. The term city is used in this report to mean agglomeration. 



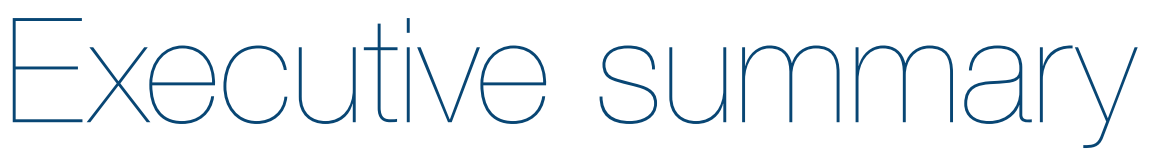

This report, composed of four West African Papers (nos. 20, 21, 22, 23) is the result of a systematic analysis of the role West African border cities play in the process of regional integration. Based on a multidimensional mapping of 18 countries, the report analyses the local dynamics that have developed in urban areas, the impact distance has on national cohesion and the impact territorial divisions have at the international level.

\section{Density, distance and division}

- At the local level, the study of demographic and morphological changes identifies the effects density has on border cities at the local level. It shows that since the mid twentieth century, the growth of border cities has almost always been greater than that of other cities in the region. This rapid growth has been especially visible within 50 kilometres of national borders, where the most dynamic markets are located. Growth has been particularly strong along Nigeria's borders and in the Gulf of Guinea between Benin and Togo. The report also confirms that border cities have very specific features. Twenty-seven of them are cross-border centres separated by land or river borders or are located on a coastline. These cross-border agglomerations emerged without a concerted development plan and remain very dependent on each other.

- At the national level, the impact of distance on border cities is studied by looking at health services and formal businesses. The map of regional health coverage shows that West African border areas are highly heterogeneous, and that the potential of harmonising the health policies of the different countries has been largely untapped. The mapping of formal businesses specialising in certain sectors of strategic importance to regional integration shows that most are located in political and/or economic capitals where decisions are made concerning customs policies as well as import/re-export strategies, and where major transportation and communications infrastructure is located. These results suggest that the lack of public investment in health services as well as roadway and education infrastructure in border regions can potentially pose major problems for national cohesion.

- At the international level, the effects of territorial divisions can be shown using an accessibility model developed to show the effects borders have on regional interactions. The results show that the population base for border cities could be 14\% larger if border crossings did not impact the flow of goods and people and 12 to 50\% larger without roadside check- 
points. Between Benin, Niger and Nigeria, an analysis of the condition of the road network shows that the combined population base of eight border cities would increase by one-third if there was no waiting at the borders. An exhaustive list of adjacent border posts in place or planned by national governments or regional organisations throughout sub-Saharan Africa further shows that trade facilitation runs up against the special interests of public servants and private-sector actors making a living from regional integration frictions. In West Africa in particular, few states are now able to benefit from the newly built border post structures in the region, most of which are not operational.

\section{Main obstacles to cross-border urban development}

The report confirms that cross-border cities lack the infrastructure needed to develop as both centres of local innovation and regional commercial hubs. This double constraint is expressed locally by urban development that is largely spontaneous and by a lack of markets, storage facilities and urban roads as well as medical, social and educational facilities. Border cities also suffer from congestion and a lack of upkeep on the road and rail infrastructure connecting them to the rest of the nation and neighbouring countries. The lack of productive, socio-educational and business investment typical of border cities considerably reduces the potential for agglomeration economies created by urban concentration. It also amplifies the negative effects of distance at the national level and imposes considerable constraints on regional trade.

From an institutional point of view, the main obstacle to the development of border cities is the low financial capacity of local and regional governments. While legal and institutional decentralisation has reached an acceptable level within the region, the tools and financial means needed to implement them are still limited. Low levels of economic independence and poor collection rates combined with a tendency to refrain from increasing taxes during election cycles are making the situation worse. Consequently, local governments lack the means to make the decentralised investments that could help them realise their urban and cross-border potential.

\section{Main recommendations}

The demographic and economic significance border cities have for regional integration justifies the need for place-based policies suited to their specific features.

- Development policies must foster the potential benefits of urban density at the local level by supporting the establishment of urban plans that maximise intra-urban interaction. The agglomeration economies created by high urban density can potentially reduce the cost of transportation and communications, foster innovation and make larger numbers of 
agricultural and manufactured products more widely available. These agglomeration economies would, however, be more easily exploitable if cities were to develop in keeping with a development plan and in concert with neighbouring border cities. The rapid population growth and urban sprawl seen today in West African border cities should encourage governments to sustainably invest in supporting these dynamics if they wish to make the most of agglomeration economies.

- Development policies should focus on reducing the distance separating border cities from other hubs in the urban network at the national level so as to minimise the inconvenience associated with their geographical marginalisation and to foster national cohesion. The development of border cities goes hand-in-hand with national policies aimed at projecting national government authority and providing services throughout the national territory.

- Development policies must continue to reduce the friction generated by the 32000 kilometres of land borders that separate the countries of West Africa at the international level. This can be achieved by facilitating the mobility of goods, people, capital and ideas over short and long distances. The transportation corridors, dry docks, joint border posts, free trade zones and pipelines currently put in place by regional organisations and national governments must be supported by development policies. 


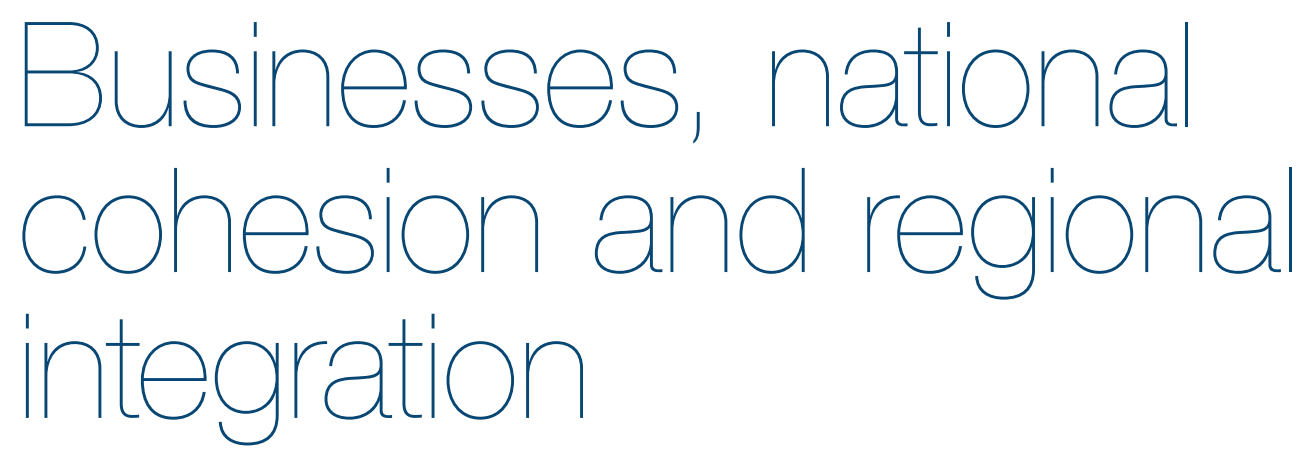

his chapter looks at the geography of formal businesses active in
economic sectors of particular importance to regional integration
such as logistics and transit, transport, marine services and interna-
tional trade. In West Africa, the analysis shows that these activities are clustered in the economic capitals, for the most part, rather than in border areas. Mali is an example that confirms the hyper-concentration of businesses in Bamako's central districts as well as the low numbers of women participating in formal economic activities in areas linked to regional integration. The results illustrate the problems many West African countries experience in distributing the potential for economic development throughout the national territory and the impact internal disparities have on national cohesion.

\section{The geography of formal businesses in West Africa}

Economic exchanges between West African countries involve a number of businesses, both formal and informal, that play a crucial role in the process of regional integration. These businesses facilitate the flow of agricultural products between surplus and deficit regions and the trade in livestock between countries in the Sahel and the Gulf of Guinea. They are also active in the international trade linking West Africa with global markets. Their contacts with Europe, North America, the Middle East and Asia enable them to provide large urban centres with manufactured products or supply a growing number of West African consumers with grain products, among other things. Lastly, these businesses help ensure that West African exports such as oil, uranium, iron, cocoa and cotton arrive at their final destination, often outside the continent.

The activities of these businesses also influence demographic growth, economic prosperity and the political scene in border cities, through which pass the containers of multinational corporations and smaller shipments from local vendors. Without this flow of textiles, used vehicles, onions, cement and market produce, border cities become less attractive to business operators and the tax revenues paid to public authorities drop. 
This chapter maps businesses specialising in economic sectors of particular importance to regional integration such as logistics and transit, transport, marine services and international trade. This regional analysis is conducted on formal enterprises whose head office and type of activity are clearly recorded in national registers. This makes it possible to measure the geographic distribution of businesses within the country and to highlight the effects of distance between capital cities and border cities.

Informal businesses active in cross-border trade, which are especially numerous in West African border areas, were not included as it would be impossible to locate all such businesses present in the region. However, the informal sector is a significant contributor to the West African economy. It accounts for at least $40 \%$ and $50 \%$ of the gross domestic product (GDP) in Benin, Chad, Mali, Senegal and Sierra Leone and over 60\% of Nigeria's GDP (Figure 1.1), as compared with an average of 17\% in OECD countries (IMF, 2017). The high percentage of GDP attributed to the informal sector, which is likely under-evaluated, is due to the formal sector's low absorptive capacity, low levels of training that encourage individual entrepreneurship from a very early age and low national government capacity to promote the documentation of economic activities. Far from being exclusively a survival strategy, the informal sector also provides an opportunity to circumvent labour and tax legislation, especially in border areas.

\section{Figure 1.1}

Percentage of GDP attributed to the informal economy, 2010-14

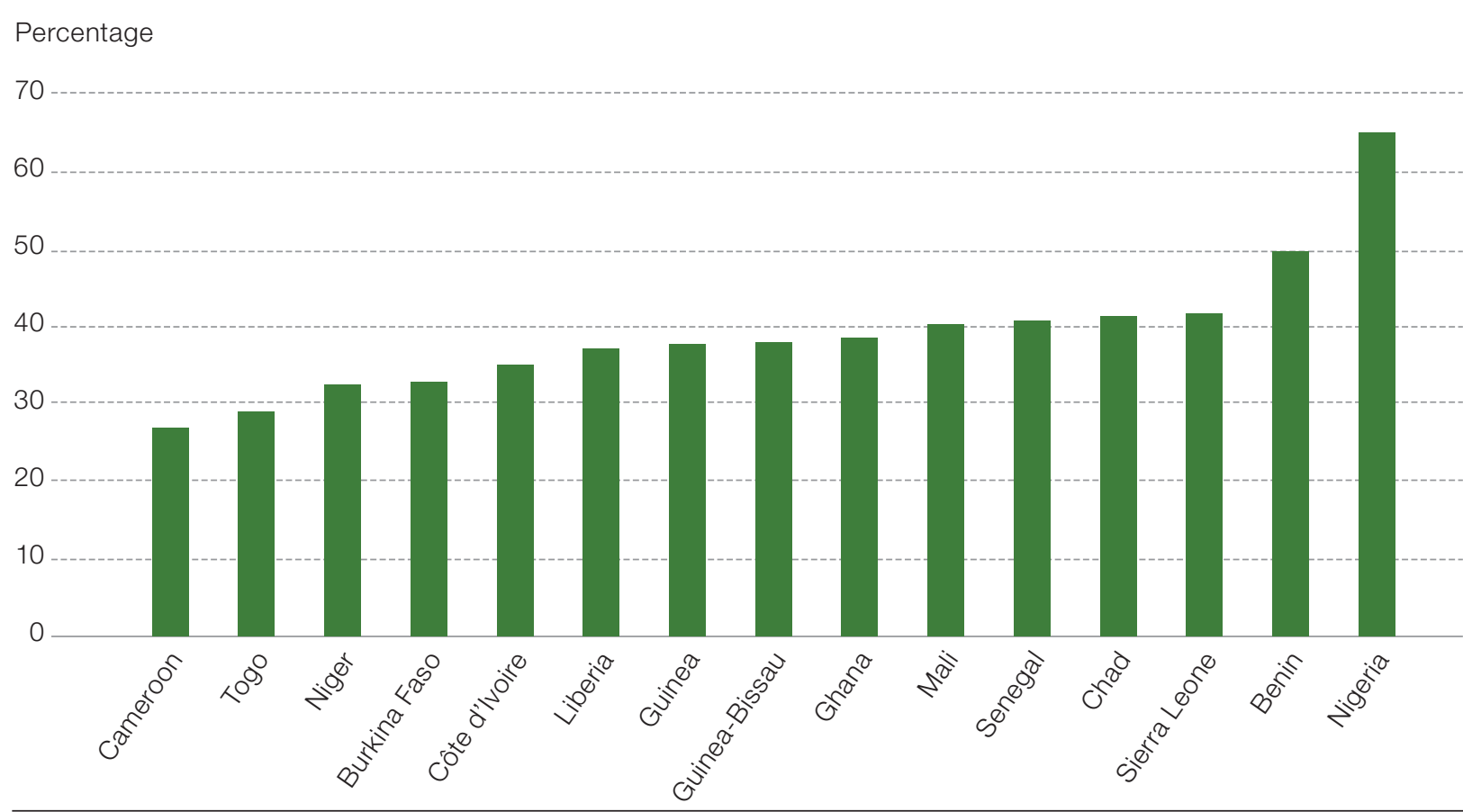

Note: The data for Gambia and Cabo Verde are missing. Source: IMF 2017. 


\section{Business sectors and regional integration}

The formal businesses studied belong to four major business sectors that contribute to the process of regional integration:

1. Logistics and transit include businesses involved in managing the flow of merchandise in the region and around the world, including activities at border-crossing points.

2. Transport includes road and rail transport. The activities of airline companies were not included as it would not be possible to distinguish regional from inter-continental flows.

3. Marine services include the materials handling and transit activities specific to ports as well as services provided to marine companies.

4. International trade includes businesses active in imports and exports. Local distribution or retail sales activities were not included as their crossborder dimension would be impossible to evaluate.

For each country, a list of businesses active in these sectors was compiled using existing national registers (West African Papers, no. 20). These registers do not always provide sufficient specific information on the sector in which a business is active. In addition, when the sectors are listed, the terminology used to describe them is not consistent across all countries. To overcome these deficiencies, the business sectors were standardised for all countries. Each business was located using geographical co-ordinates and then assigned to a city in the region.

There are over 472000 formal businesses in West Africa, of which 12652 (3\%) are active in economic sectors deemed important for regional integration in 2016 (Table 1.1). Even in a region with a high level of trade activity such as West Africa, most formal businesses serve a local or national market. Those with the skills and finances needed to serve the regional market are rare. As such, in most countries with exhaustive national registers, less than $10 \%$ of formal businesses can be deemed active in the trade and transport sectors. The percentage is especially low in Nigeria (2\%), despite the fact that $69 \%$ of all businesses in the region are located there as are over half of the businesses active in the area of regional integration. The figure is above 10\% in Burkina Faso (16\%), Cabo Verde (12\%) and Chad (12\%) only, due to the significance of import-export activities in those countries.

The geography, economic heft and specialisation of some countries explains, in part, the variations between the different countries. Countries with developed port, rail and road infrastructure, such as Côte d'Ivoire, Ghana and Nigeria, are home to a number of businesses specialised in international 
trade, for example. National differentials may also be partially attributed to the quality of the data available. Some countries have a complete database, including Burkina Faso, Ghana, Mali and Nigeria, while the lack of national registers in other countries makes it impossible to give a comprehensive overview of national businesses. Due to the differences between countries,

Table 1.1

Number of formal businesses and quality of data per country and type, 2016

\begin{tabular}{|c|c|c|c|c|}
\hline Country & $\begin{array}{r}\text { Total number } \\
\text { of formal } \\
\text { businesses }\end{array}$ & $\begin{array}{r}\text { Formal } \\
\text { businesses } \\
\text { active in } \\
\text { the area of } \\
\text { regional } \\
\text { integration }\end{array}$ & $\begin{array}{r}\text { Percentage } \\
\text { of formal } \\
\text { businesses } \\
\text { active in the } \\
\text { area of regional } \\
\text { integration }\end{array}$ & Quality of data \\
\hline Nigeria & 326410 & 6506 & 2.0 & Good \\
\hline Mali & 42646 & 2360 & 5.5 & Excellent \\
\hline Ghana & 23379 & 786 & 3.4 & Good \\
\hline Burkina Faso & 3370 & 544 & 16.1 & Good \\
\hline Côte d'Ivoire & 34658 & 433 & 1.2 & Average \\
\hline Togo & 19766 & 375 & 1.9 & Average \\
\hline Senegal & 7141 & 328 & 4.6 & Average \\
\hline Benin & 2770 & 275 & 9.9 & Average \\
\hline Chad & 2099 & 258 & 12.3 & Average \\
\hline Niger & 8779 & 236 & 2.7 & Average \\
\hline Cabo Verde & 1526 & 187 & 12.3 & Average \\
\hline Mauritania & - & 125 & - & Insufficient \\
\hline Guinea & - & 105 & - & Insufficient \\
\hline Liberia & - & 51 & - & Insufficient \\
\hline Guinea-Bissau & - & 46 & - & Insufficient \\
\hline Sierra Leone & - & 31 & - & Insufficient \\
\hline Gambia & - & 9 & - & Insufficient \\
\hline Grand Total & 472544 & 12655 & 2.7 & \\
\hline
\end{tabular}

Note: There is no complete database for Gambia, Guinea, Guinea-Bissau, Liberia, Mauritania or Sierra Leone. It is therefore it impossible to calculate the total number of businesses in all sectors combined.

Source: national registers (see West African Papers, no. 20) 
Table 1.2

Number of formal businesses per country and per sector, 2016

\begin{tabular}{|c|c|c|c|c|c|}
\hline Pays & $\begin{array}{r}\text { Logistics and } \\
\text { transit }\end{array}$ & Transportation & $\begin{array}{r}\text { Marine } \\
\text { services }\end{array}$ & $\begin{array}{r}\text { International } \\
\text { trade }\end{array}$ & Total \\
\hline Benin & 51 & 22 & 20 & 182 & 275 \\
\hline Burkina Faso & 2 & 135 & & 407 & 544 \\
\hline Cabo Verde & 8 & 7 & 4 & 168 & 187 \\
\hline Côte d'Ivoire & & & & 433 & 433 \\
\hline Gambia & & & & 9 & 9 \\
\hline Ghana & 335 & 9 & 45 & 397 & 786 \\
\hline Guinea & & & & 105 & 105 \\
\hline Guinea-Bissau & & & & 46 & 46 \\
\hline Liberia & & & & 51 & 51 \\
\hline Mali & 335 & 507 & 3 & 1515 & 2360 \\
\hline Mauritania & 9 & 39 & & 77 & 125 \\
\hline Niger & 55 & 21 & & 160 & 236 \\
\hline Nigeria & 1998 & 428 & 405 & 3675 & 6506 \\
\hline Senegal & 103 & 41 & 21 & 163 & 328 \\
\hline Sierra Leone & 1 & & & 30 & 31 \\
\hline Chad & 37 & 68 & 2 & 151 & 258 \\
\hline Togo & & & & 375 & 375 \\
\hline Total & 2934 & 1277 & 500 & 7944 & 12655 \\
\hline
\end{tabular}

Source: national registers (see West African Paper no. 20)

the core of the analysis addresses subnational dynamics between capital and secondary cities, rather than making international comparisons.

More than six out of ten businesses are involved in international trade, which is by far the most highly represented sector with close to 8000 businesses, followed by logistics and transit with about 3000 businesses (23\%). Only one out of ten businesses is active in transport, while the more specialised marine services sector accounts for 500 businesses, or $4 \%$ of the total number (Table 1.2). 


\section{Figure 1.2}

Percentage of formal businesses active in the process of regional integration present in economic capitals, 2016

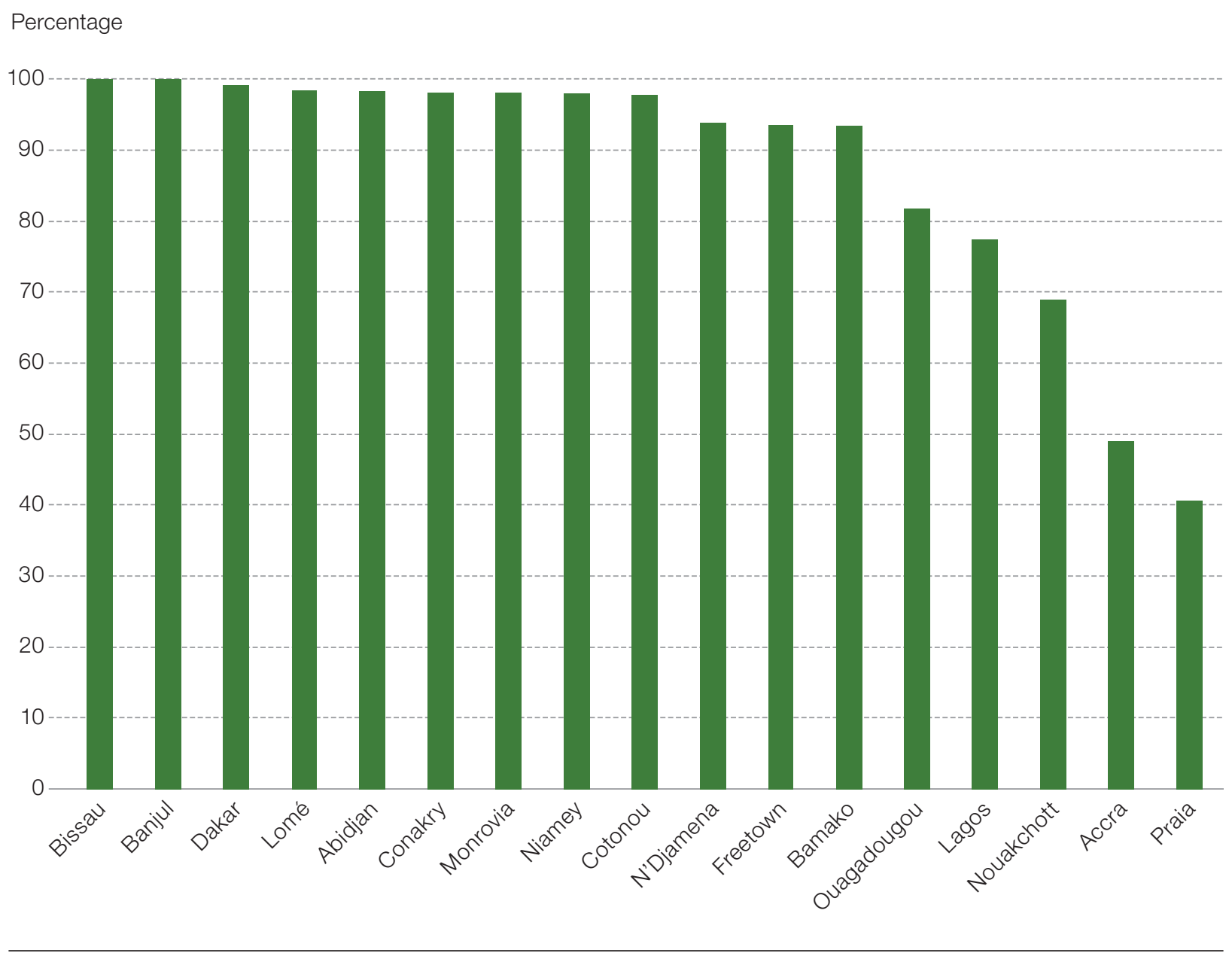

Source: national registers (see West African Papers, no. 20)

\section{Most businesses are clustered in capital cities}

Businesses active in the process of regional integration are heavily concentrated in the economic capitals of West African countries (Table 1.3). In many respects, the geographic distribution of businesses active in the area of regional integration is more uneven than that of the population, which in many countries features a pronounced macrocephaly.

In countries where economic and political functions are clustered together in one city, a significant proportion of businesses active in the process of regional integration are located in the capital. The percentage for the economic capital approaches 100\% in Benin, Gambia, Guinea, Guinea-Bissau, Liberia, Niger, Senegal and Togo, while Bamako, Freetown and N'Djamena are home to more than $90 \%$ (Figure 1.2). 
Table 1.3

Cities with the highest number of businesses active in the process of regional integration, based on distance from a border, 2016

\begin{tabular}{|c|c|c|c|c|c|c|c|c|c|}
\hline & $20 \mathrm{~km}$ & & $50 \mathrm{~km}$ & & $100 \mathrm{~km}$ & $>100 \mathrm{~km}$ & & West Africa & \\
\hline 1 & Lomé & 369 & Lomé & 369 & Lagos & Bamako & 2202 & Lagos & 5028 \\
\hline 2 & N'Djamena & 242 & Cotonou & 269 & Lomé & Ouagadougou & 445 & Bamako & 2202 \\
\hline 3 & Calabar & 40 & N'Djamena & 242 & Cotonou & Abidjan & 425 & Ouagadougo & ou 445 \\
\hline 4 & Nouadhibot & u 38 & Calabar & 40 & N'Djamena 242 & Accra & 384 & Abidjan & 425 \\
\hline 5 & Falémé & 12 & Nouadhibot & 38 & Niamey & Dakar & 325 & Accra & 384 \\
\hline 6 & & & Katsina & 15 & Conakry & Téma & 260 & Lomé & 369 \\
\hline 7 & & & Falémé & 12 & Bissau & Onitsha & 144 & Dakar & 325 \\
\hline 8 & & & & & Calabar & Aba & 140 & Cotonou & 269 \\
\hline 9 & & & & & Nouadhibou 38 & Ibadan & 130 & Téma & 260 \\
\hline 10 & & & & & Freetown & Kano & 130 & N'Djamena & 242 \\
\hline
\end{tabular}

Note: Only cities with more than ten businesses were included.

Source: national registers (see West African Papers, no. 20)

In Mauritania, Nouakchott faces competition from Nouadhibou, where businesses involved in international and maritime trade are located. In Ghana, the smaller percentage of businesses present in Accra is due to the fact that many businesses are, in reality, established in the neighbouring port of Tema. Together, the two cities account for 644 businesses, as compared with only 45 in Kumasi, the Ashanti metropolis in the country's interior. The primacy of the economic capital over the political capital is visible in Nigeria, where Lagos is home to over 5000 businesses, or $77 \%$ of the figure for the entire country and $40 \%$ of the total at the regional level, as compared with only 61 in Abuja. The same scenario was seen in Abidjan (425 businesses) as compared with Yamoussoukro (0) and in Lomé (369) as compared with Porto-Novo (1). The Cabo Verde archipelago is the only country where a relatively even distribution was observed between the capital city of Praia and the cities of Mindelo and Espargos, specialised in port activities.

The uneven geographical distribution of formal businesses is visible in Map 1.1, which shows, in addition to the role of capital cities, a clear distinction between ports in the Gulf of Guinea and the large urban centres in the Sahel. With the exception of Nigeria, which has a diversified urban network, very few businesses active in the area of regional integration are located in the Sudanian area through which pass significant flows of goods and people but which has few large metropolitan areas. 
The relative importance of West African economic capitals is linked to historic factors. During the colonial period, capital cities served as administrative centres and market hubs, especially in cities along the Gulf of Guinea from where the main railroad routes to the interior of the colonies originated. By concentrating both politics and business in a small number of cities, which were often newly established, the colonial land-use model reinforced the internal territorial disparities in West Africa that were already significant due to low densities, long distances and territorial divisions.

The relative demographic and economic clout of capital cities in relation to older urban centres increased during the post-colonial period. The creation of new capitals such as Abuja in Nigeria and Yamoussoukro in Côte d'Ivoire resulted in the relocation of political functions but did not slow the demographic and economic development of primate cities (see West African Papers, no. 21). The capital city is an urban environment unlike any other in the rest of the country due to investment, high-level functions and infrastructure unique to that type of urban centre. It functions as a political showcase for governments and a key point of entry and exit for the flows of people and materials linking the country to the rest of the world. In addition, it is in capital cities that the future of border cities is played out as they are, more so than other cities, subject to the changes in customs regulations, border closings, embargos and international conflicts.

\section{Few formal businesses present in border cities}

More than half (52\%) of the 12655 businesses active in the process of regional integration are located less than 100 kilometres from a border (Figure 1.3). However, this high percentage must be considered in relative terms insofar as the distance criterion includes eight economic capitals whose activities do not exclusively depend on cross-border trade or transport (Bissau, Conakry, Cotonou, Freetown, Lagos, Lomé, N’Djamena and Niamey). The number of businesses quickly drops as distance from a border decreases: only 1000 of them (8\%) are located less than 50 kilometres away and at 20 kilometres away, the number falls to less than 750 , or a mere $6 \%$. These results indicate that border areas are practically devoid of formal businesses active in the process of regional integration, which however, rely on regional trade. The low number of formal businesses contrasts sharply with the profusion of informal businesses that are omnipresent in border cities.

At a short distance, the border agglomerations of Lomé and N'Djamena logically account for the largest number of businesses, as does Cotonou, situated at less than 50 kilometres from Nigeria (Table 1.3). At less than 100 kilometres from a border, the central role played by Lagos, with 5028 businesses, is unparalleled in the region. Onitsha, the second Nigerian city, has only 144 businesses, despite the fact that it has the second-largest population in West Africa, Lagos being the largest. 


\section{Map 1.1}

Formal businesses active in the process of regional integration per city, 2016

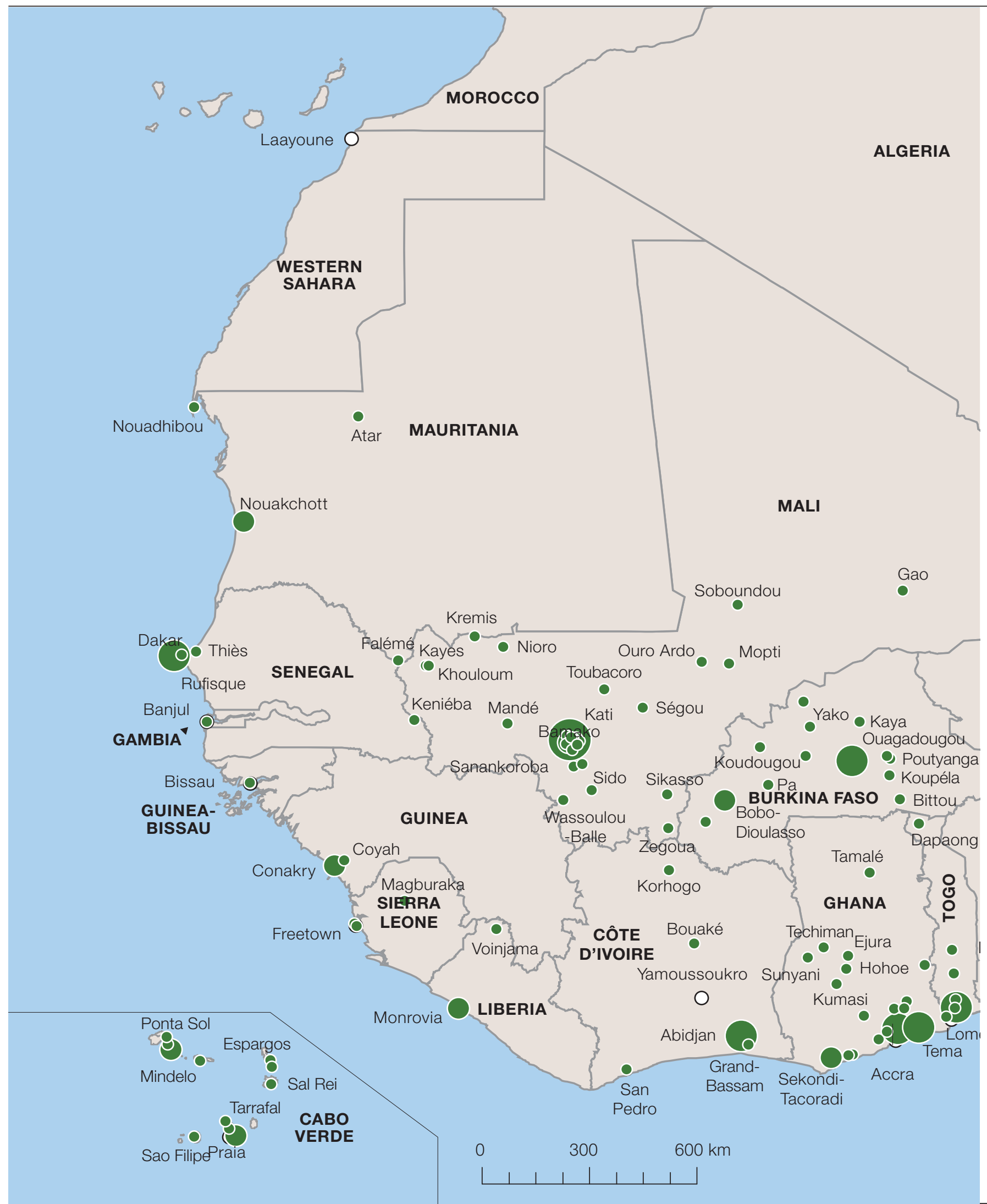

Note: In the interest of legibility, not all city names were included. Source: national registers (see West African Papers, no. 20) 


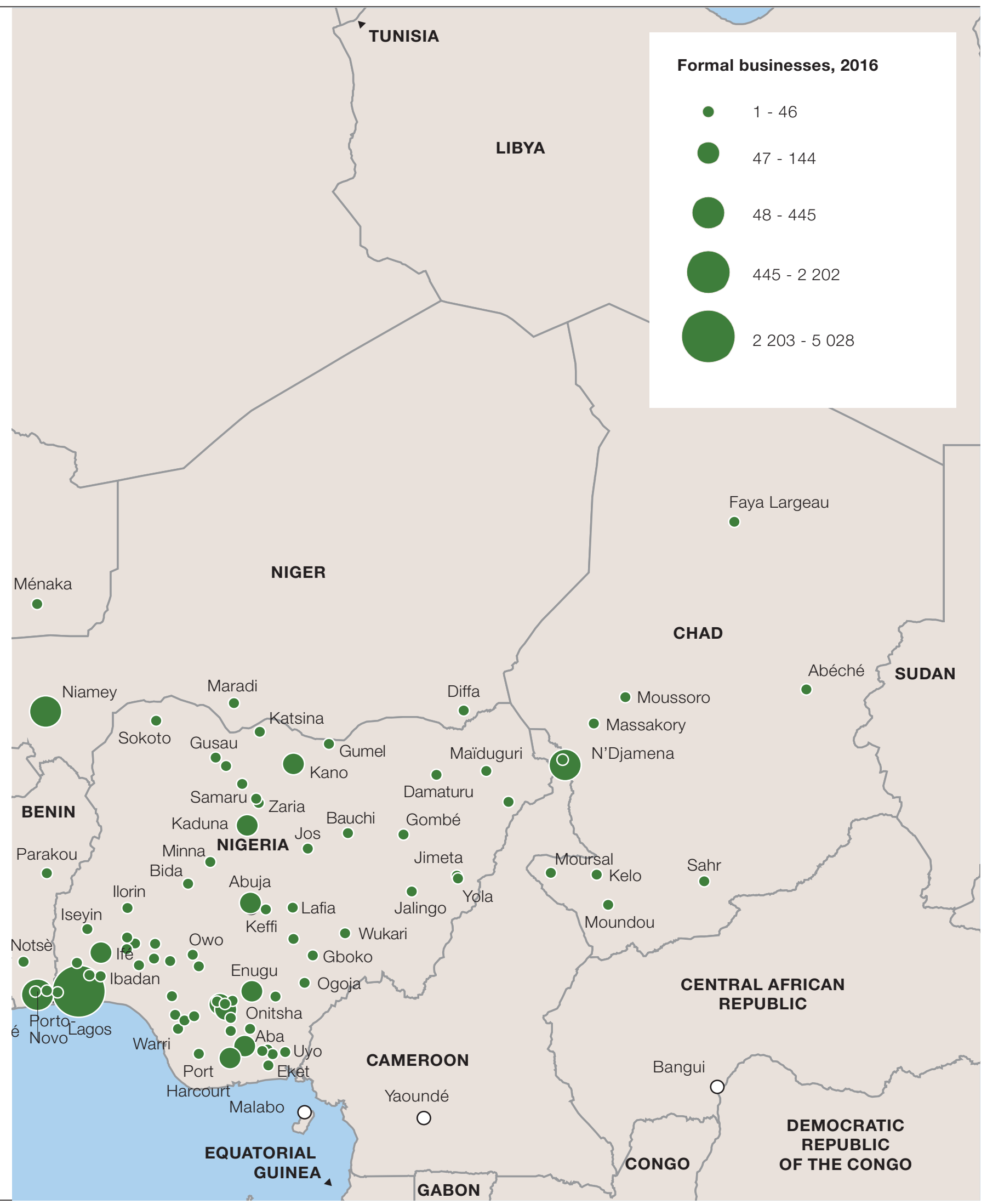




\section{Figure 1.3}

Number of formal businesses active in the process of regional integration at a given distance from a border, 2016

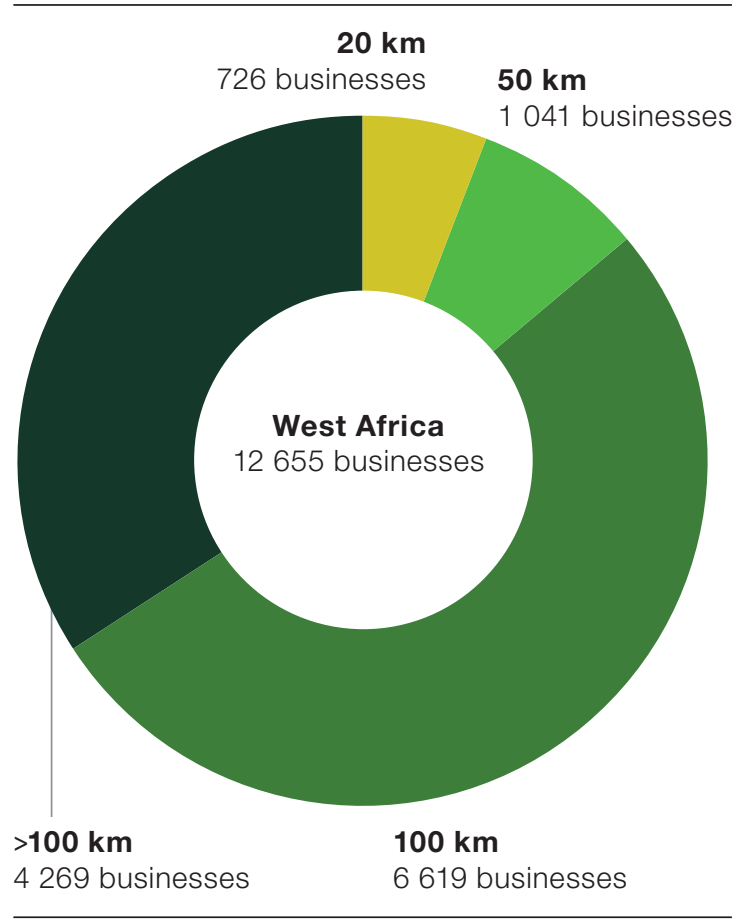

Source: national registers (see West African Papers, no. 20)
Businesses that operate at the regional level from a head office located in a capital city maintain only a minor presence in border cities, namely representatives working in the markets or adjacent to a customs office. Most of their work is done in government offices and with shippers, which does not require the businesses to make significant investments in fixed assets.

\section{Formal businesses in Mali}

Mali has the most detailed data in West Africa on the sector, location and legal form of businesses. The gender of business owners is also provided, which makes it possible to show spatial and social inequalities in the region.

The unsurpassed clout of Bamako In Mali, the capital city of Bamako dominates by far the national urban hierarchy. Between 1960 and 2000, the population of the city skyrocketed

from 128000 to 1234000 people. It is estimated that the city will be home to 3.2 million inhabitants by 2020, or close to half of Mali's urban population, as compared with only 320000 in Sikasso and less than 250000 in Ségou, Koutiala and Kayes (OECD/SWAC, 2018).

This demographic dominance is even more pronounced in relation to the economy. The head office of close to nine out of ten formal businesses in Mali is located in one of the six municipalities within the District of Bamako, all sectors of the economy included. The figure is 95\% for the greater Bamako urban area, which extends beyond its institutional boundary toward Kati to the north and along the right bank of the Niger River. The relative importance of secondary cities is negligible in comparison: Kayes is home to only 351 businesses, Ségou 212 and Sikasso 131. The heavy concentration of formal businesses in the capital indicates that most economic activity in the country's other cities is in the hands of informal entrepreneurs.

Consequently, Mali's capital city is home to a disproportionate number of businesses active in sectors of crucial importance to regional integration. More than nine out of ten businesses active in logistics, transit, transport and international trade have their head office in the Bamako region (Map 1.2). 


\section{Map 1.2}

Distribution of formal businesses in Mali's cities, 2016

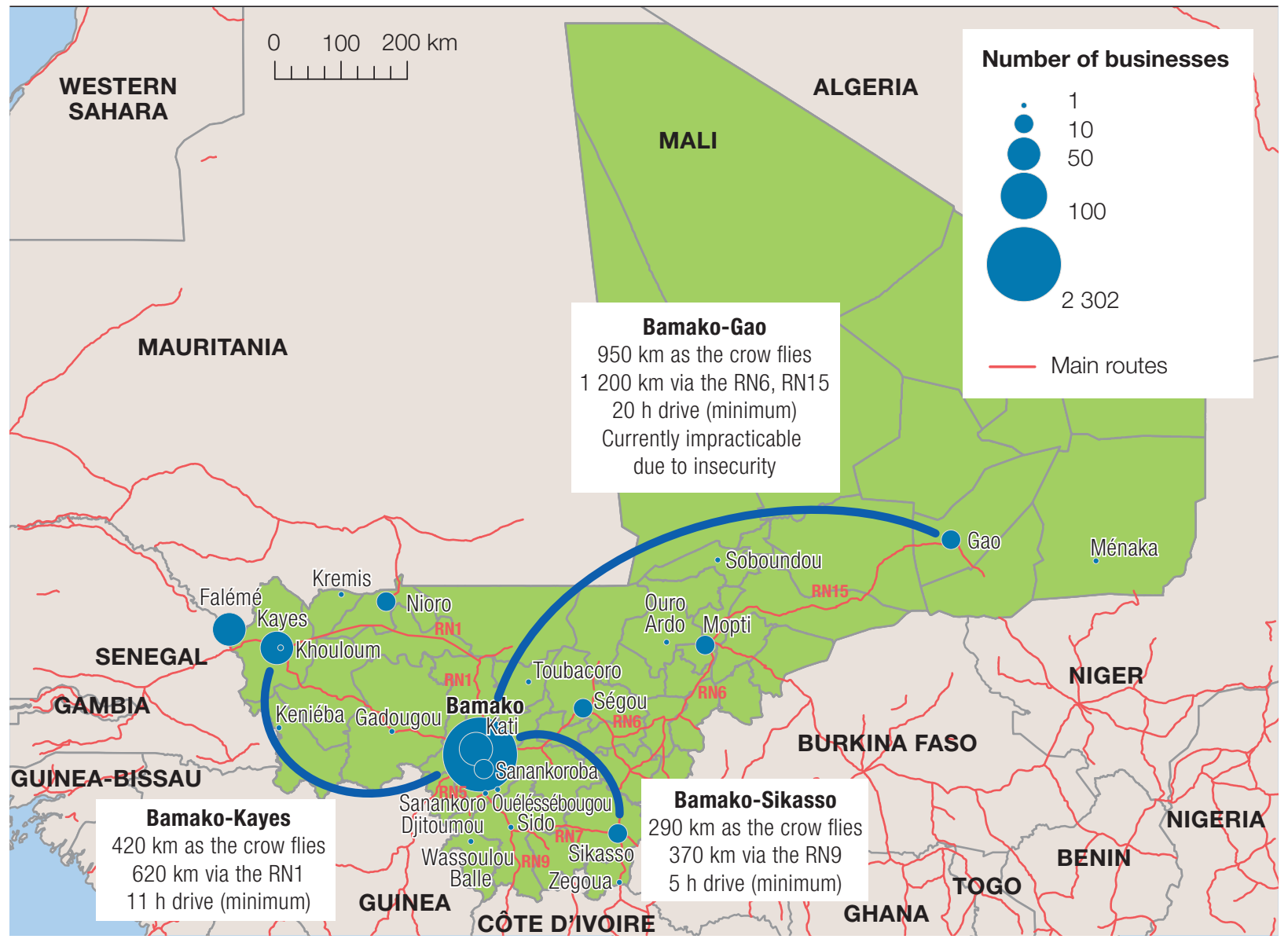

Sources: ApiMali 2017 and Google Maps 2018

The other secondary centres are located in the Kayes region on the borders with Senegal and Mauritania, where most businesses are involved in crossborder transit, and to a lesser extent in some of the country's regional capitals (Sikasso, Gao and Mopti).

This hyper-concentration of formal businesses in the capital city is made even more problematic by the low density of the road network and the very long distances that must be travelled to reach key border crossings. It takes at least five hours to travel from Bamako to Sikasso in the southern part of the country when traffic conditions are ideal, which is far from the case in the region given the number of vehicles, roadside checkpoints and the condition of the roads (see West African Papers, no. 23). The city of Kayes, which has been linked to Bamako by paved road for twelve or so years, is more than an eleven-hour drive from the capital on national highway 1, whereas Gao is located 1200 kilometres from Bamako and has been inaccessible since the civil war began in 2012. 


\section{Geography of the Bamako agglomeration}

In the Bamako urban region, businesses active in areas linked to transit, import-export and logistics are especially numerous along the right bank of the Niger River in the city's Municipality V (482) and VI (560) (Map 1.3). This part of the Bamako agglomeration has experienced spectacular land development in recent decades, due to demographic growth, clientelism arrangements that foster the sale of peripheral lands and the depletion of the District's land reserves (Bertrand, 2015). Close to 44\% of all formal businesses working in these sectors in Mali are located in these two municipalities located near the international airport. On the left bank, there is also a high concentration of businesses in Municipality II (326) where the industrial park is located, around the main market in Municipality III (311) and in Municipality IV (362). Very few businesses are located in the municipalities on the periphery of Bamako such as Mandé (4), Kati (11) and Baguinéda-Camp (4).

From a sector-based point of view, the largest number of businesses are involved in import-export activities, accounting for $65 \%$ of the total number of formal businesses. Bamako's six municipalities host almost all formal businesses active in the sector in Mali (Table 1.4), with the highest concentration in the southern part of the agglomeration. In Municipality VI, these businesses are clustered in the areas of Faladie (80) where the General Customs Directorate is located, Magnambougou (65), Banankabougou (54) and Sogoniko (34) facing the Niger River. Logistics and transit are fairly evenly distributed among the central municipalities. Transport activities are located mostly in the areas of Kalaban Coura, Baco Djicoroni and Faladié

Table 1.4

Businesses by sector and municipality, 2016

\begin{tabular}{lr:r:r|r|r}
\hline Municipality & $\begin{array}{r}\text { Import- } \\
\text { Export }\end{array}$ & Logistics & Transit & Transport & Total \\
\hline Bamako Municipality I & 109 & 11 & 15 & 37 & 172 \\
\hline Bamako Municipality II & 231 & 18 & 18 & 59 & 326 \\
\hline Bamako Municipality III & 229 & 7 & 22 & 53 & 311 \\
\hline Bamako Municipality IV & 205 & 21 & 40 & 96 & 362 \\
\hline Bamako Municipality V & 342 & 22 & 30 & 88 & 482 \\
\hline Bamako Municipality VI & 323 & 23 & 52 & 162 & 560 \\
\hline Total Bamako & 1439 & 102 & 177 & 495 & 2213 \\
\hline Total Mali & 1526 & 109 & 203 & 533 & 2371 \\
\hline
\end{tabular}

Source: ApiMali 2017 
which are located in proximity to major roadways and the airport in the southern part of the capital, as well as in the areas of Hamdallaye (241) and Centre Commercial (161) in Municipalities IV and III.

\section{Women are under-represented}

Other than a very high concentration in the capital, the data on Mali also shows that national businesses are largely owned by men. Only 15\% of formal businesses throughout the country and in all sectors are owned by women. More businesses in the service, sales and restaurant sectors as well as the medical-social field are owned by women (Table 1.5). Inversely, the percentage of women involved in technology, construction and mining is quite low. These results are similar to those obtained for OECD countries, which show an over-representation of women in the social, teaching, health care and sales fields (OECD, 2018).

In sectors deemed representative of the regional integration process, the percentage of women is lower than the national average (11.5\%) (Figure 1.4).

Table 1.5

The ten activities in which women have the highest and lowest levels of representation in Mali, 2016

\begin{tabular}{l|l}
\hline High percentage of women & Low percentage of women \\
\hline Other activities and services (61.8) & $\begin{array}{l}\text { Construction, building and public works; } \\
\text { engineering (5.3) }\end{array}$ \\
\hline Wholesale or on-commission sales (44.4) & $\begin{array}{l}\text { New information and communications } \\
\text { technology (5.6) }\end{array}$ \\
\hline Hotels and restaurants (38.0) & Real estate activities (5.7) \\
\hline Health and social assistance (31.8) & Transports, ancillary transport activities and \\
\hline Sanitation and waste collection (27.2) & communications (5.8) \\
\hline Teaching (25.0) & $\begin{array}{l}\text { Production and distribution of electricity, gas } \\
\text { and water (6.1) }\end{array}$ \\
\hline Health and social action (24.8) & Extractive and mining activities (6.9) \\
\hline Leisure, cultural and sporting activities (23.1) & Photography (7.1) \\
\hline Retail sales (21.7) & Agriculture and hunting and related services \\
\hline Education, training and research (18.2) & (7.6) \\
\hline
\end{tabular}

Note: The percentage of businesses owned by a woman is indicated in parentheses. Only those sectors with more than ten businesses where no gender data is missing were included.

Source: ApiMali 2017 


\section{Map 1.3}

Distribution of businesses per sector in the Bamako urban area, 2016

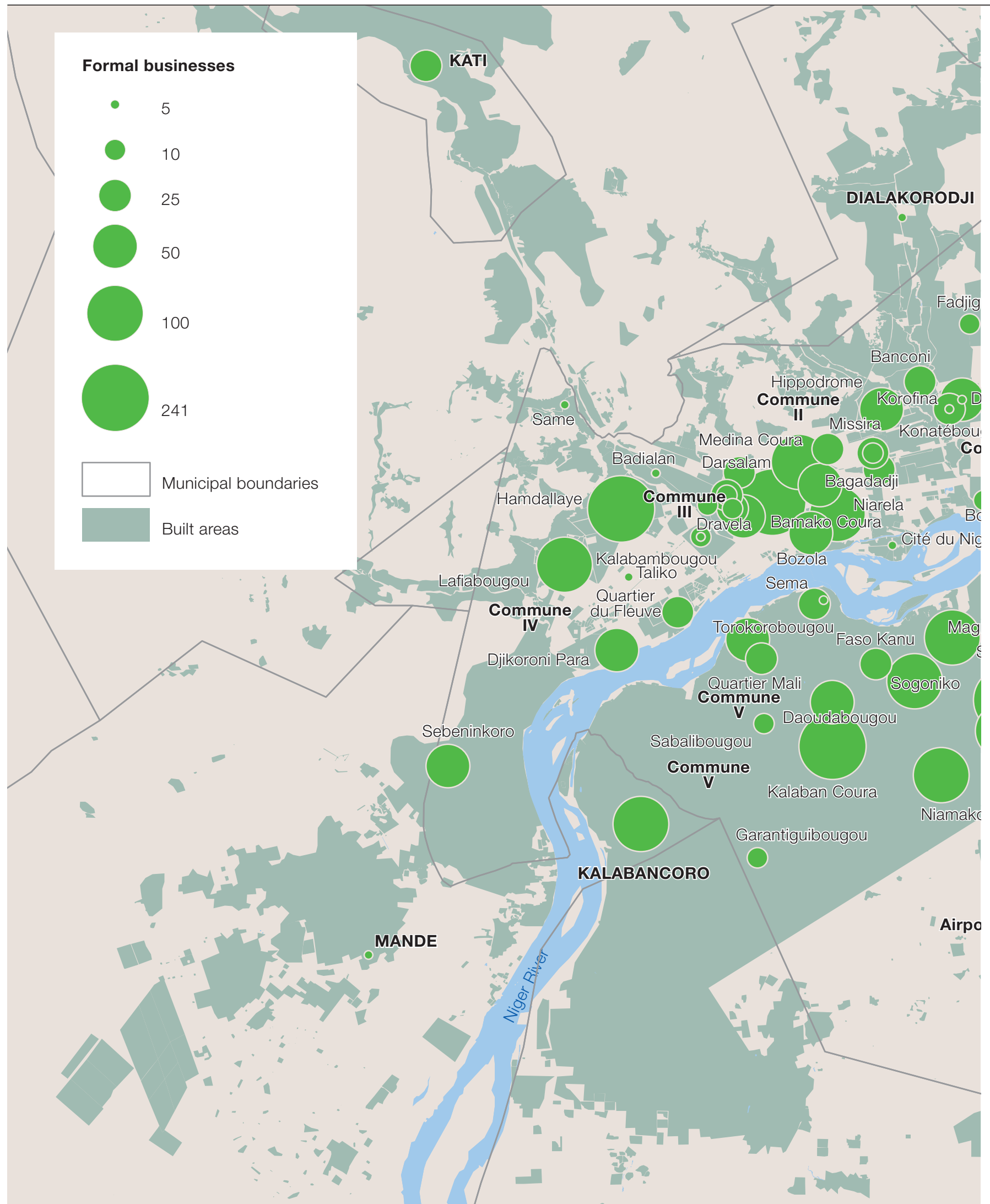

Source: ApiMali 2017 


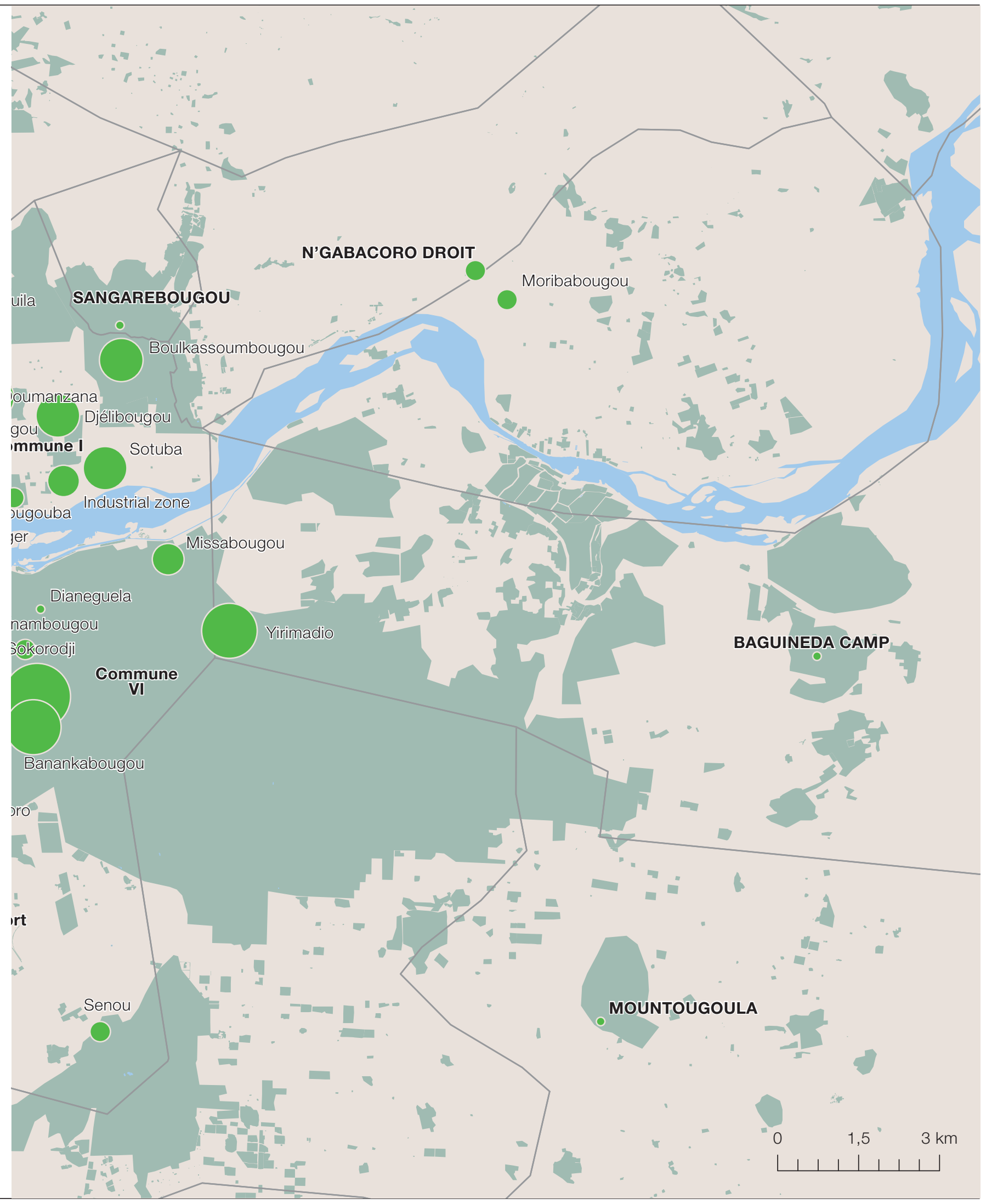


The number of women involved in import-export is slightly higher than in other sectors due to the number of them who operate small businesses, particularly in Bamako's large markets. However, it was noted that eight out of ten women operate small businesses as sole proprietorships rather than as a company, which suggests that the average size of these women-owned businesses is relatively small and that employees are family members, for the most part. This is particularly true in the import-export sector where almost all women-owned businesses are sole proprietorships. As for transport transit and logistics companies, they are dominated by limited liability companies.

\section{Disparities and national cohesion}

The economic activity of West African countries is largely concentrated in the economic capitals, including sectors associated with regional integration such as international trade or transit, which affect border areas the most. This geographic hyper-concentration of formal and informal businesses is an indication of the challenge faced by many West African countries in redistributing economic potential throughout the national territory.

This has been a recurring problem since the precolonial period. Precolonial powers attempted to overcome the low densities and long distances in West Africa by encouraging the activities of trade networks relying on a cluster of cities without, however, seeking to control the territory between them (Lovejoy, 1980; Walther et al., 2015). Due to sparse settlement patterns and the meagre military resources allocated to controlling territory, the

\section{Figure 1.4}

Gender of Mali's business owners based on sector, 2016

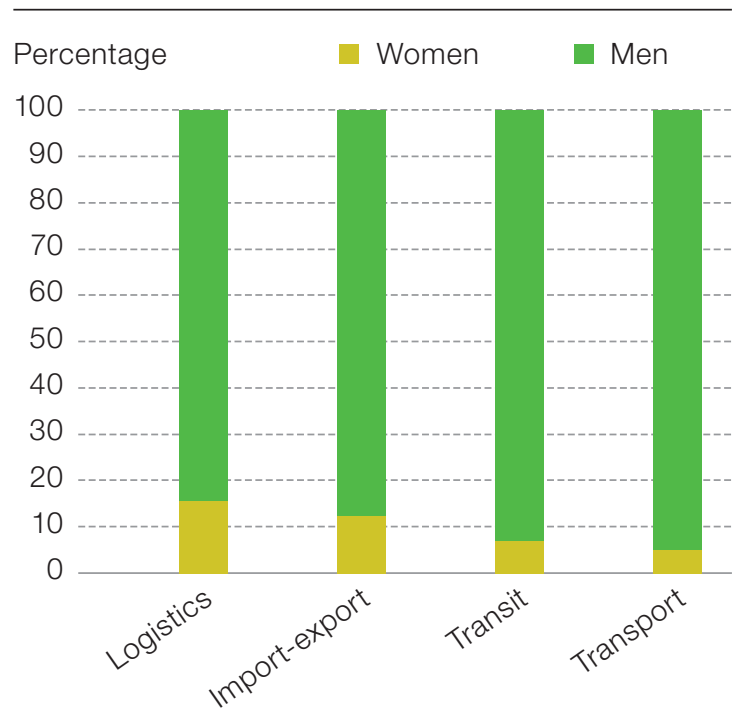

Note: Only businesses for which the gender of the owner is known were included. Source: ApiMali 2017 authority of precolonial nation-states was not exerted much beyond the perimetre of influence of the capital, even in the most centralised of states, such as the Ashanti Empire. In the Sahel in particular, peoples living in the peripheries were subject to slavery raids or made to pay tribute to the central powers, although they did not exert any effective control over these populations.

During the colonial period, the small number of territorial administrators led the colonial powers to reproduce the precolonial system of remote governance (Herbst, 2002). For example, in northern Mali, France delegated its power to some local groups such as the Kel Adagh Tuaregs and the Kunta 
Arabs, a practice that has been used by postcolonial governments until the present day (Boilley, 1996; Grégoire, 2013). Chronic under-investment in the colonies, justified by the principle according to which they were to finance themselves, also resulted in a fragmented road and rail network (Debrie, 2010). As such, West Africa has inherited a transport network oriented more to global markets than internal connections to the region, a model that is quite different than the perfectly connected network geographers of the 1960s had envisaged for the region (Taaffe et al., 1963). Incapable of overcoming the obstacles related to low density and long distances, the network could not effectively contribute to the internal cohesion of the colonies.

The West African transport network was only marginally completed during the postcolonial period. In the 1970s, some major transport routes intended to foster national unity from east to west were built in Mauritania (Highway of Hope), Niger (Highway of Unity) and Mali (Bamako-Gao Highway). These investments in roadways were interrupted in the mid-1980s with the advent of structural adjustment policies that resulted in a substantial reduction in infrastructure investments and the privatisation of transport companies. This period of austerity seemed to come to an end in the 2010s when the African Union's Program for Infrastructure Development in Africa (PIDA) was launched and a number of major projects were undertaken (see West African Papers, no. 23). These projects backed by African regional organisations, international financial institutions and supported by public-private partnerships intend to respond to the isolation of Sahelian countries by building rail links in order to foster trade relations between major urban centres by way of transportation corridors (Oliete Josa and Magrinyà, 2018).

The enthusiasm for new regional infrastructure projects backed by African and international organisations should not result in overlooking the low density of existing networks - Nigeria excepted - or recurring problems with maintaining transport infrastructure. For example, although Mali gained its independence close to 60 years ago, the city of Timbuktu is still not linked by paved road to the rest of the national network ${ }^{1}$, not to mention cities in the Ifoghas like Kidal, whose physical inaccessibility preceded the triggering of a civil war in Mali in 2012.

Observed or perceived disparities between the capital and its provinces described in this chapter by way of formal businesses, makes fragile the process of national cohesion. By slowing down internal trade among countries in the region, they open up areas that bypass the region's central powers or are governed by delegation from the capital. These internal disparities feed certain political movements with aspirations of greater autonomy from the central powers or demands for radical changes in social

1 The Niono-Timbuktu road financed by the European Union for 197 million euros is scheduled to be completed by the end of 2018. The terrorist attacks that occurred in the Soumpi region in October 2017 and January 2018, caused the interruption of the road construction. 
and religious practices. Both centrifugal trends, which come together in Mali, are likely to endanger national unity and integrity. National governments in the region have, therefore, every interest in reducing them by way of policies that are more attuned to the spatial effects of economic growth (ADB/OECD/UNDP, 2015). 

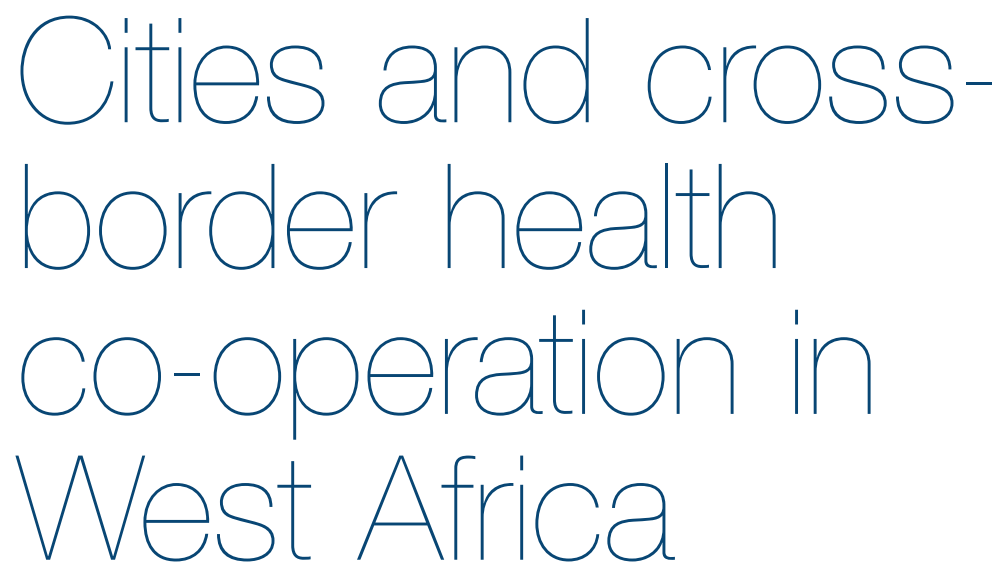

his chapter analyses the geographic distribution of West Africa's health
infrastructure and the role border cities play in cross-border health
co-operation. A ground-breaking mapping focuses on health facilities
which are large enough to encourage local people to travel for health care and, consequently, foster institutional co-operation between border cities. At the national level, health infrastructure mapping shows that border cities have a surplus of medical centres and a deficit of hospitals and maternity facilities in relation to urban population size. At the regional level, the analysis identifies several regions where closer collaboration could lead to establishing crossborder health facilities.

\section{Medical progress and infranational disparities}

Sub-Saharan Africa has made remarkable progress on health since the beginning of the 2000s. The crude death rate dropped from 39\% to 34\% between 2000 and 2015, while the child mortality rate plummeted from 94\%o to 55\% during the same time period (UNICEF, 2018). Much progress has been made in the area of prevention, which has also helped significantly reduce the number of malaria victims whose numbers dropped from 764000 to 395000 between 2000 and 2015. Prevention also helped contain the HIV/ AIDS epidemic for which the number of new infections has been steadily declining since the early 2000s (WHO, 2017). Consequently, the average life expectancy increased from 50 to 60 years between 2000 and 2015, after a period of stagnation during the 1990s (United Nations, 2017). However, the progress made at the continental level continues to mask great disparities across regions, especially in relation to developmental delays and childhood diseases caused by poor diet, recurring infections and inadequate psychosocial stimulation.

Between 2000 and 2015, almost all African countries saw a reduction in the absolute levels of stunting, emaciation and underweight in children under 


\section{Map 2.1}

Stunting in children under the age of five, 2000

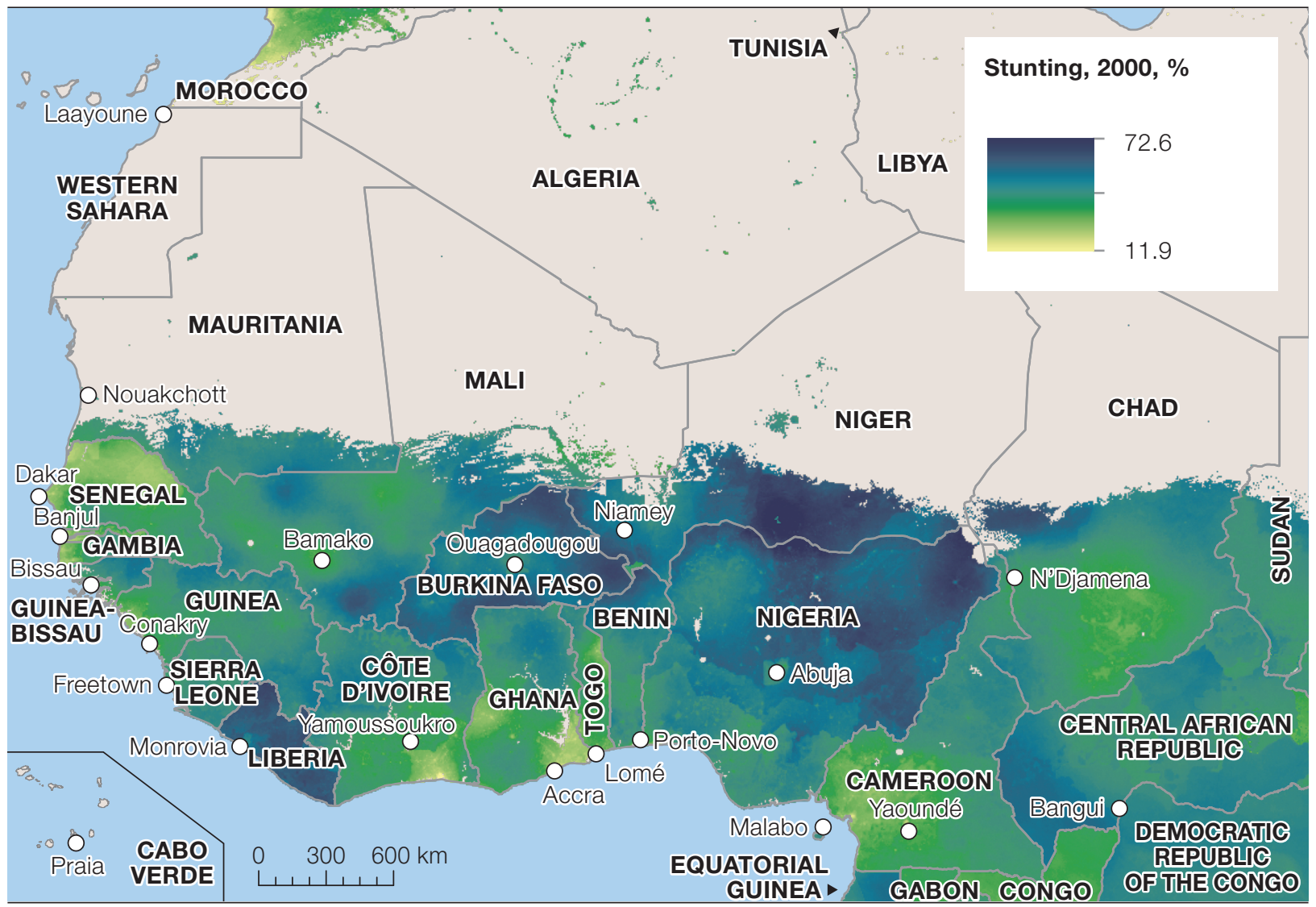

Source: adapted from Osgood-Zimmerman et al. 2018

the age of five. If this trend continues, many African countries will achieve the World Health Organization's (WHO) global nutrition targets for 2025. In West Africa, for example, Burkina Faso, Mali and Senegal have made considerable progress over the past 15 years in that regard throughout most of their national territory (Maps 2.1 and 2.2). In the Sahel, while stunting is rapidly declining, it is still a significant problem in some areas (Osgood-Zimmerman et al., 2018). There are also great internal disparities in Chad, Niger and Nigeria. The rate of growth for children under the age of five is particularly slow on the Niger-Nigeria border and in the area around Lake Chad.

Similar disparities have been observed with respect to the change in the child mortality rate since 2000. While sub-Saharan Africa has the highest child mortality rates in the world, the number of children who die before reaching the age of five has decreased dramatically in many countries, especially in the central and eastern parts of the continent (Golding et al., 2017). In West Africa, the situation is more heterogenous: while the level in the eastern part of the Gulf of Guinea is encouraging, over 120 deaths per 1000 live births were still being observed in Chad, Mali and Sierra Leone in 2015 (Maps 2.3 and 2.4). Health is still a major concern in the Lake Chad area where the lack 


\section{Map 2.2}

Stunting in children under the age of five, 2015

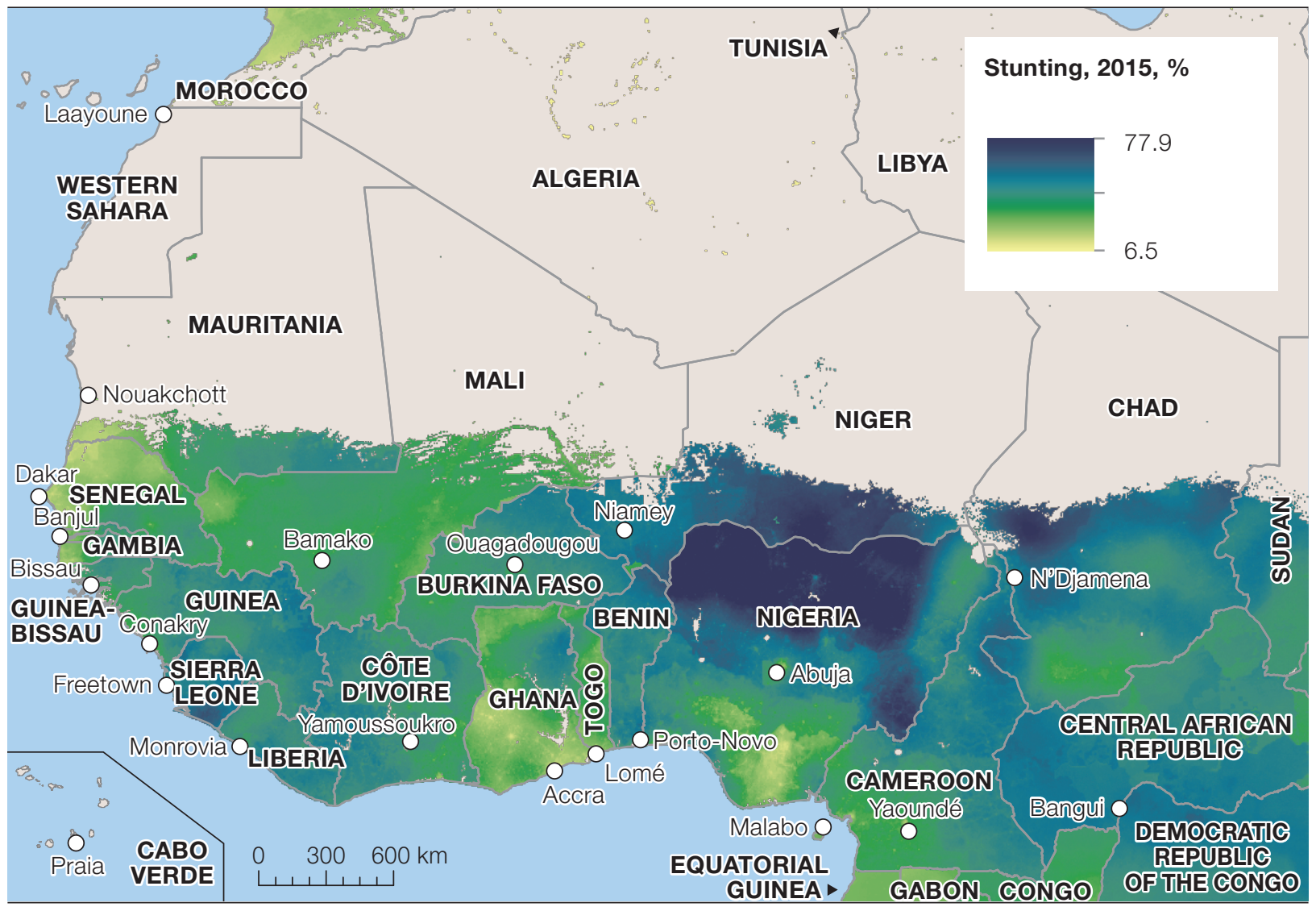

Source: adapted from Osgood-Zimmerman et al. 2018

of physicians, mid-wives and hospital beds means that women give birth at home, which exposes them and their children to additional risks in the event of complications (Magrin et al., 2015).

Generally speaking, the greatest health disparities were observed within rather than between countries. While the child mortality rate was 115 per 1000 live births in Nigeria in 2015, it was 55 \% in Osun state in the southwestern part of the country and $215 \%$ in Bauchi state in the northeast. Similarly, the large urban centres have far superior health indexes than do other regions, especially the economic and political capitals. From that perspective, Abuja, Bamako, Ouagadougou and Niamey seem to be developed pockets within large less-favoured regions.

The health indicators also show remarkable cross-border continuities in areas where data was collected on the same dates using identical protocols. With respect to stunting, for example, similar values were seen in 2015 between south-eastern Nigeria and western Cameroon; on the Benin-Nigeria border in Borgou; between western Côte d'Ivoire, Liberia and Guinea; along the coast in Ghana and Togo; in Senegambia as well as the Burkina Faso/Niger 


\section{Map 2.3}

Mortality rate for children under the age of five, 2000

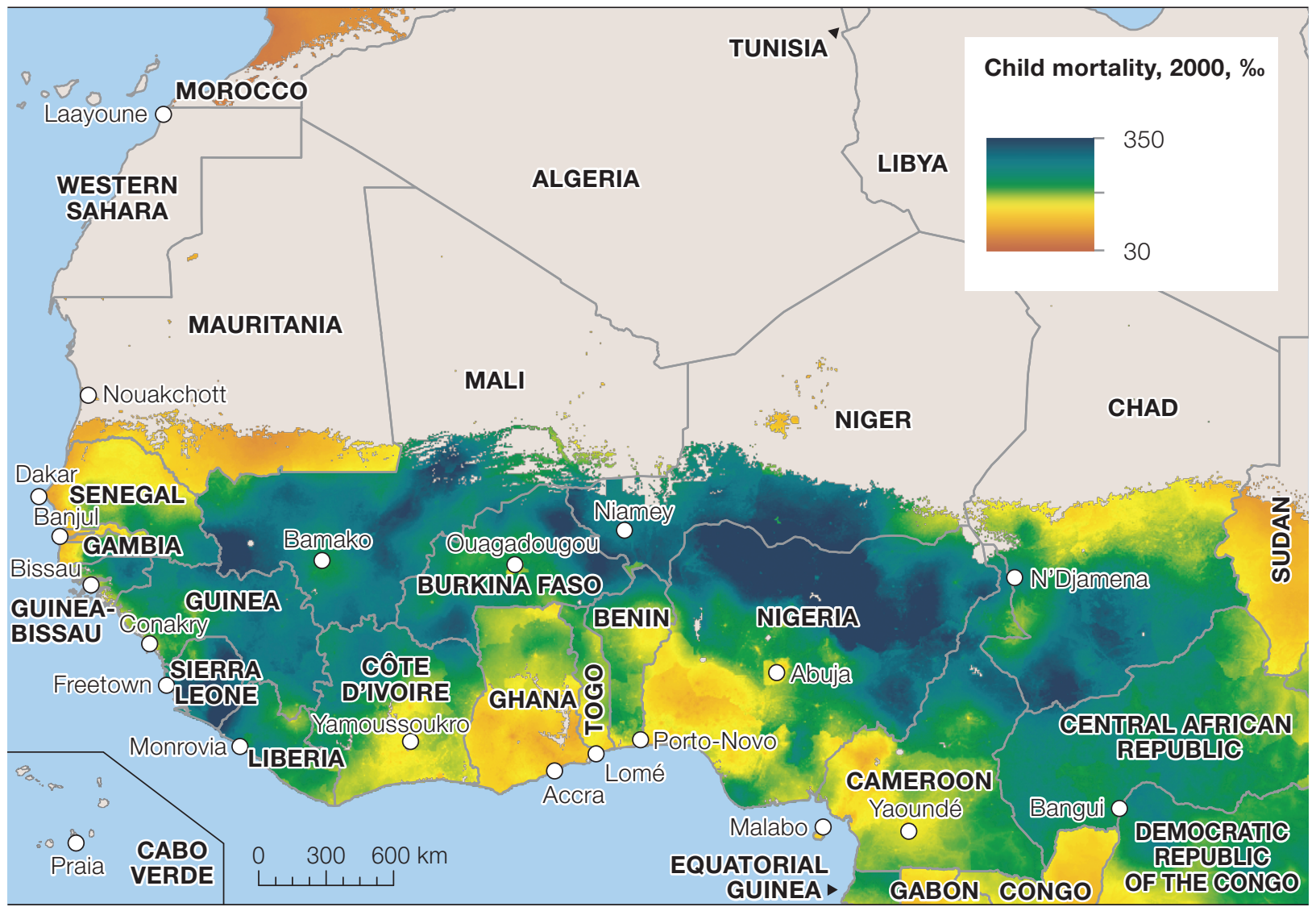

Source: adapted from Golding et al. 2017

region of Liptako-Gourma (Map 2.2). Mapping child mortality clearly shows analogous continuities in, for example, Fouta Djalon in north-eastern Côte d'Ivoire and on the Gulf of Guinea coast (Map 2.4).

Some of the strong contrasts observed between some countries in the region are due to the different collection methods employed. In some countries, only one data sample on the total number of deaths was collected, while in others several exhaustive surveys were conducted and used to reconstruct the biographical path of the survey subjects. Consequently, some of the border differentials observed should not be interpreted as different levels of health development but rather as an unintended artefact of the field surveys. Such is the case in Nigeria, where stunting and infantile mortality in 2015 seemed to be artificially higher than in Niger during the same time period, whereas the health coverage in Nigeria is far superior to that of its neighbour to the north (Maps 2.2 and 2.4). Similar differentials exist between Côte d'Ivoire and Ghana as well as between Mali and Mauritania for the same indicators. These statistical biases make it all the more necessary to build a cartography of health coverage independent of national definitions. 


\section{Map 2.4}

Mortality rate for children under the age of five, 2015

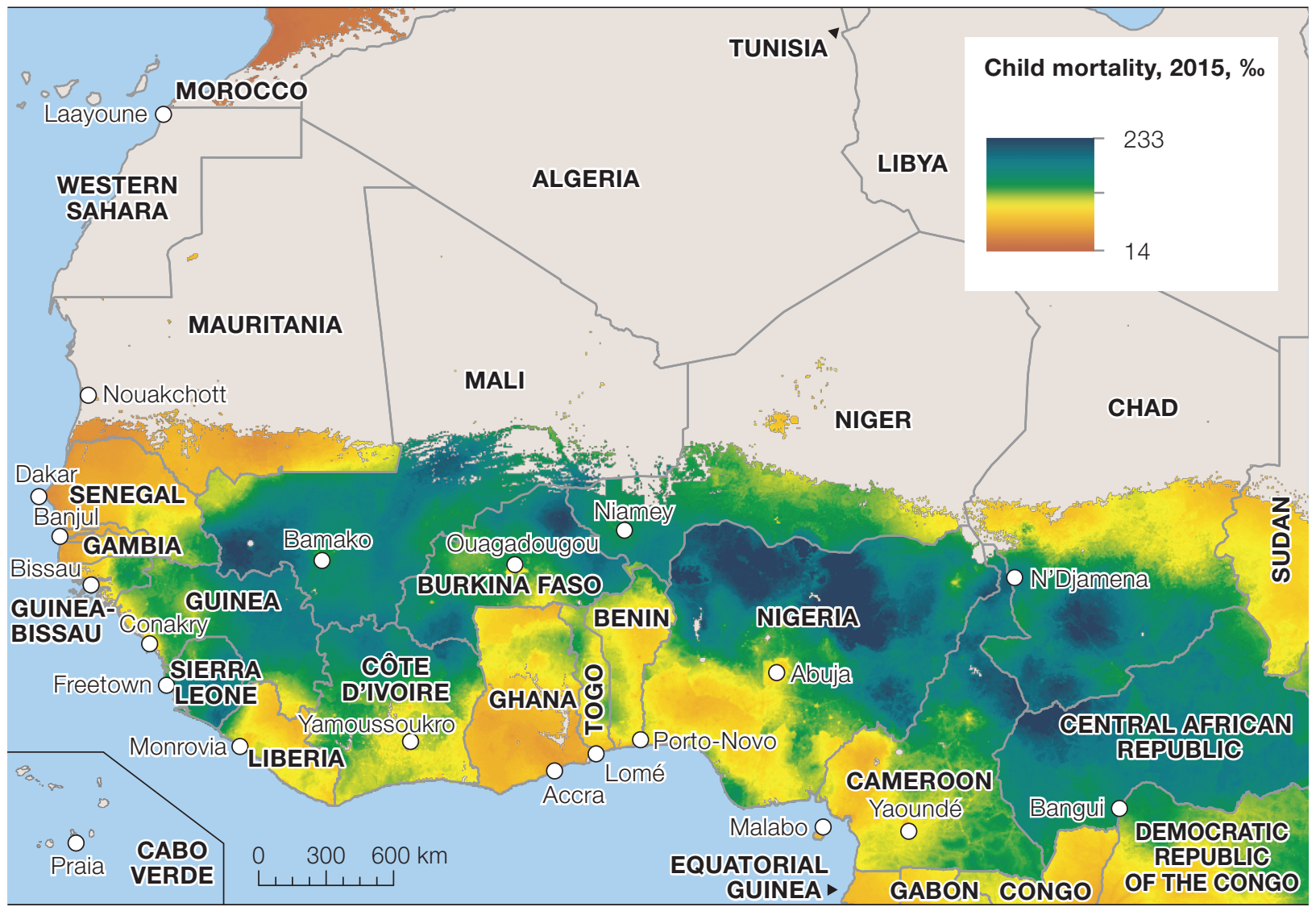

Source: adapted from Golding et al. 2017

\section{A health coverage cartography}

The health infrastructure maps in this chapter were used to assess the role border cities play in national and regional health dynamics and to highlight the potential for cross-border health co-operation. This cartography analyses the degree to which border cities are more or less well-equipped than the rest of the national territory before identifying the cities and regions with the potential for enhanced cross-border health co-operation.

The "health map" of West African countries is based on health facilities whose services become increasingly specialised with distance from the local area. Four main categories of health facilities were identified.

- Hospitals constitute the top tier of national coverage. These establishments serve the region or entire nation, depending on the size of the country, and have the most complete and specialised facilities. The polyclinics, regional hospitals and university hospitals in Burkina Faso, Chad, Mali and Niger as well as the regional, central and prefectural hospitals in Guinea fall into this category. 
- Maternity facilities include those attached to a hospital as well as independent establishments. For that reason, they are considered top-tier facilities.

- Health centres constitute the middle tier of the medical hierarchy. These centres, which offer a variety of medical services but do not treat the most serious cases, include the clinics in all countries (with the exception of Liberia and Sierra Leone where clinics fall under the health unit category), referring health centres and inter-enterprise medical centres (centres de santé de référence and centres médicaux interentreprises) in Mali and Niger, municipal health centres (centres de santé de commune) in Benin, health centres in Chad, medical centres with a surgery unit in Burkina Faso as well as type 1 and 2 integrated health centres (centres de santé intégrés de types 1 et 2) in Côte d'Ivoire. District hospitals in Niger, departmental hospitals in Benin, district hospitals in Chad as well as the departmental hospitals in Mauritania were also included in this category due to their small size.

- Health units occupy the lower tier of the national medical hierarchy. They provide primary or community-based care at dispensaries, infirmaries and medical-social structures. These units include community health centres (centres de santé communautaires) in Mali, neighbourhood and community health centres (centres de santé d'arrondissement et unités villageoises) in Benin, health and social promotion centres (centres de santé et de promotion sociale) in Burkina Faso, health posts and integrated health centres in Niger, health units (postes de santé) in Guinea and Senegal, basic and primary health centres in Ghana and Nigeria, rural and urban health centres in Côte d'Ivoire, community clinics in Ghana, community health centres and clinics in Sierra Leone, socio-medical centres and clinics in Liberia as well as peripheral care units in Togo.

These establishments play very different roles in border regions. Hospitals and maternity facilities are generally specialised and well-equipped but are few in number within the national territory. Border populations are, in theory, inclined to travel long distances or cross a border to access these top-tier facilities where they can access suitable care. As such, these facilities have greater potential to attract cross-border patients than those that serve locals, such as health units, and are distributed relatively evenly throughout the territory. Consequently, the top-tier facilities are those whose potential for cross-border co-operation is the most interesting for local populations and the most profitable for the national governments concerned.

\section{Eight out of ten health facilities are located in Nigeria}

There are at least 46103 health establishments in West Africa (Table 2.1). Health centres and hospitals each account for $12 \%$ of them, while $6 \%$ are maternity facilities. Close to 32000 facilities (69\%) are modestly equipped health units 
Table 2.1

Number of health establishments per country and type, 2017

\begin{tabular}{|c|c|c|c|c|c|}
\hline Country & Units & Centres & $\begin{array}{r}\text { Maternity } \\
\text { facilities }\end{array}$ & Hospitals & Total \\
\hline Nigeria & 25564 & 3929 & 2576 & 5107 & 37176 \\
\hline Côte d'Ivoire & 1458 & 235 & 62 & 80 & 1835 \\
\hline Sierra Leone & 1170 & 298 & 13 & 99 & 1580 \\
\hline Mali & 1189 & 300 & 6 & 37 & 1532 \\
\hline Chad & 1317 & 58 & unknown & 22 & 1397 \\
\hline Liberia & 365 & 353 & 11 & 54 & 783 \\
\hline Niger & 271 & 65 & 7 & 27 & 370 \\
\hline Burkina Faso & 224 & 51 & 9 & 35 & 319 \\
\hline Senegal & 249 & 34 & unknown & 19 & 302 \\
\hline Ghana & 1 & 102 & 4 & 125 & 232 \\
\hline Benin & 66 & 78 & 8 & 52 & 204 \\
\hline Guinea & 61 & 81 & 2 & 23 & 167 \\
\hline Togo & 25 & 52 & 2 & 35 & 114 \\
\hline Mauritania & 10 & 24 & 2 & 15 & 51 \\
\hline Gambia & 1 & 21 & unknown & 4 & 26 \\
\hline Guinea-Bissau & unknown & 2 & unknown & 7 & 9 \\
\hline Cabo Verde & unknown & 3 & unknown & 3 & 6 \\
\hline Total & 31971 & 5686 & 2702 & 5744 & 46103 \\
\hline
\end{tabular}

Source: Global Healthsites Mapping Project

serving local populations. The proportion of health units to middle- and top-tier centres is over 75\% in Chad, Côte d'Ivoire, Mali and Senegal.

Considering the size and population of each country helps show that some, such as Guinea-Bissau, Mauritania and Niger have relatively few facilities despite strong population growth - due to state resources earmarked for healthcare (Figure 2.1).

In addition, complete, country-wide data is not always available (Burkina Faso, Benin, Mauritania and Senegal), especially for health units for which geolocation data may be missing (Chad and Liberia) or only partially listed 
Figure 2.1

Per-country density of health facilities, 2017

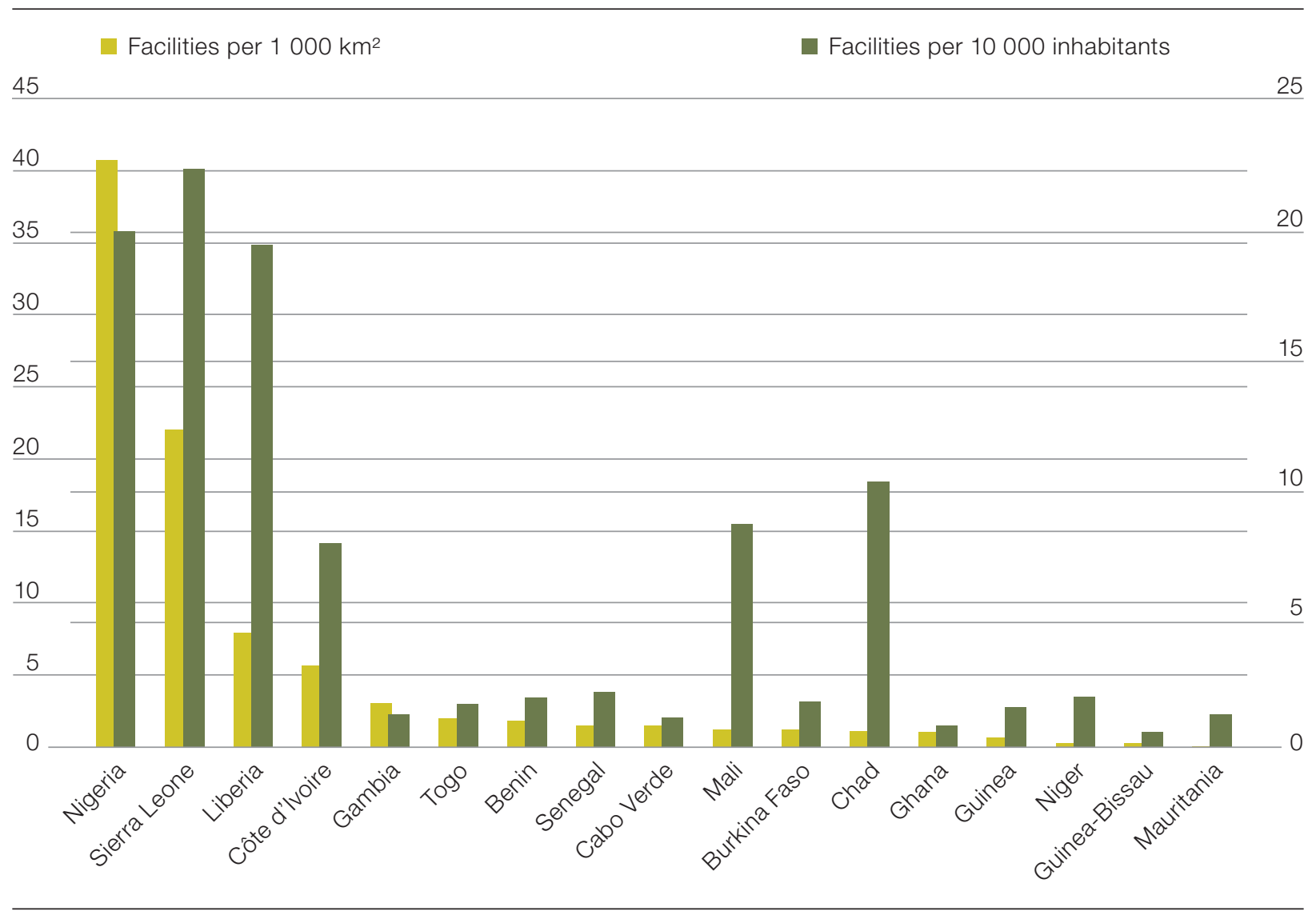

Source: Global Healthsites Mapping Project

(Cabo Verde, Ghana, and Guinea-Bissau). These statistical biases lead to focusing the study on domestic variations rather than international comparisons (Map 2.5).

Health coverage density is highest by far in Nigeria, where $80 \%$ of the region's health facilities are located (Map 2.6). The percentage is higher for hospitals (89\%) and maternity facilities (95\%) than for medical centres (70\%). The health infrastructure in Nigeria is unparalleled in the region: with 37176 establishments, it is 100 times more developed in absolute figures than is Niger (370) whereas Nigeria, which has a population of 187 million people, was a "mere" ten times larger than its neighbour to the north in 2015. Nigeria's regional pre-eminence makes it impossible to map the average density of health facilities, as the distortions caused by the country's high densities clouds the dynamics in other countries.

Within Nigeria, however, two large cluster areas were identified: the large metropolitan area of Lagos-Ibadan-Illorin, which covers Yorubaland, and the Onitsha metropolitan region, in Iboland and Ibidioland, which stretches down 
to the Niger River delta toward Port-Harcourt and Calabar in the south. Both regions extend beyond Nigeria's borders in the direction of Cotonou and of Cameroon (Map 2.6). At less than 50 kilometres from a land border, few other regions are truly integrated from a health perspective. On the contrary, the medical development gap between Nigeria and its neighbours is quite obvious, including between Katsina and Maradi or Birnin Kebbi and Dosso in the north.

\section{Fewer health facilities in border areas}

There are 830 health establishments located less than 20 kilometres from a land border in West African countries (Figure 2.2). The health centres in the middle tier of the medical hierarchy are especially numerous in these border areas as they account for $72 \%$ of the regional total. At 50 kilometres away, more than 2100 facilities were identified, of which 20\% are hospitals and $10 \%$ are maternity facilities. Over 5300 establishments are located less than 100 kilometres from a border. The percentage of health centres drops quickly in the interior of the countries and here account for only $56 \%$ of establishments as compared with one-third for hospitals. These results suggest that the health equipment in border areas differs from that found in other areas of West African countries.

Figure 2.2

Establishments by type and distance from a border, 2017

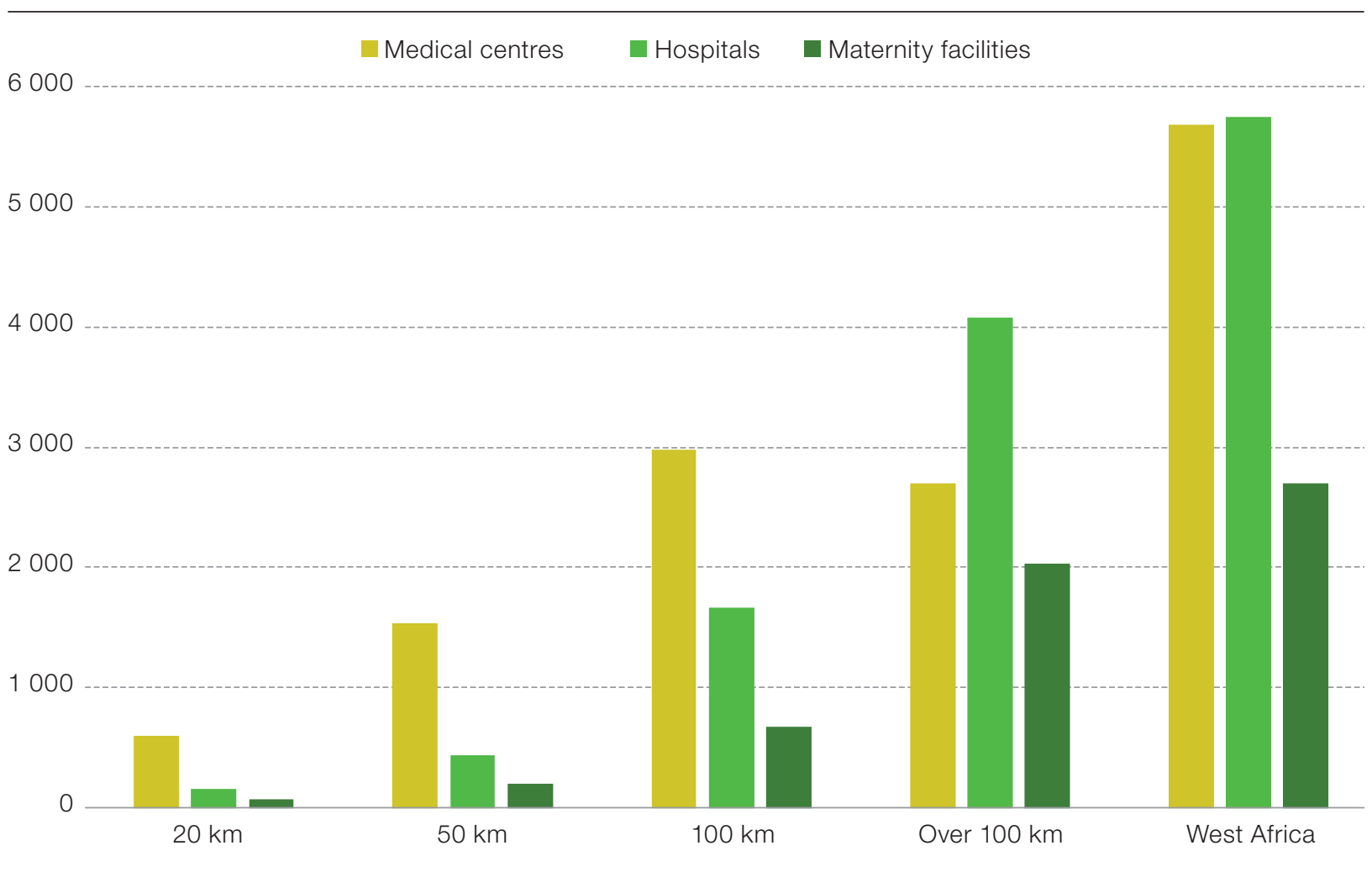

Source: Global Healthsites Mapping Project 


\section{Map 2.5}

Regional health coverage by type of facility, 2017

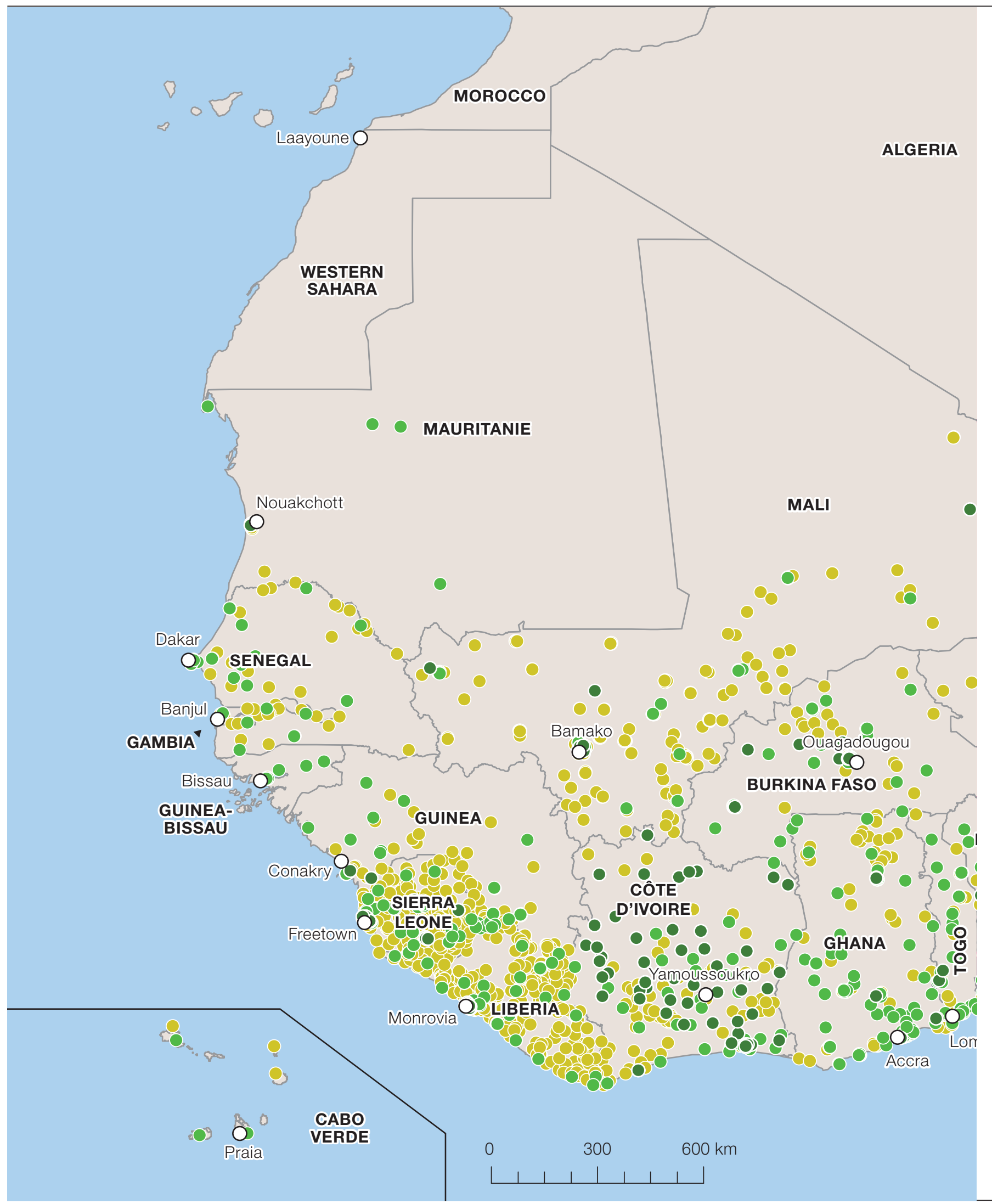




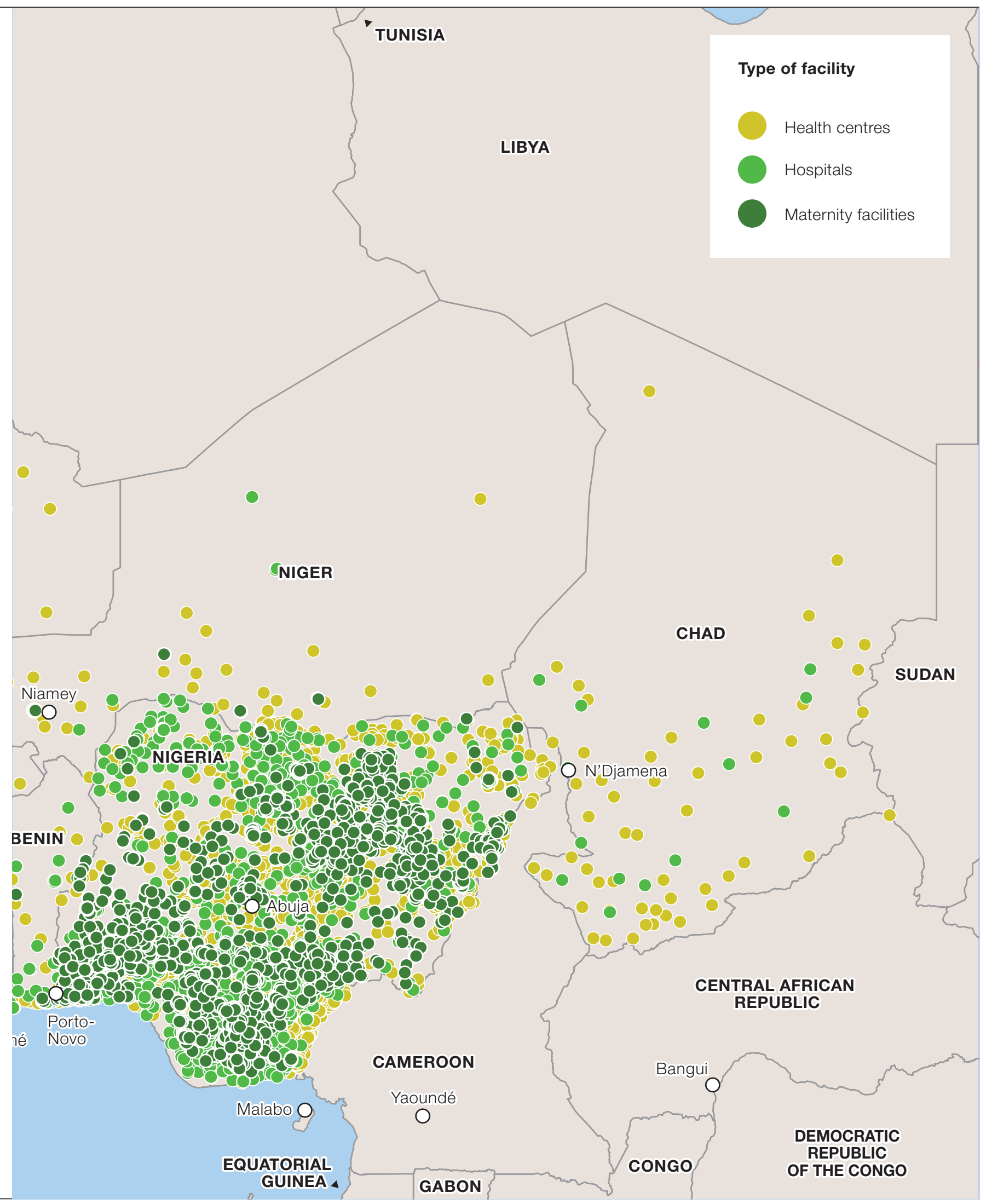


Map 2.6

Health facilities in Nigeria, 2017

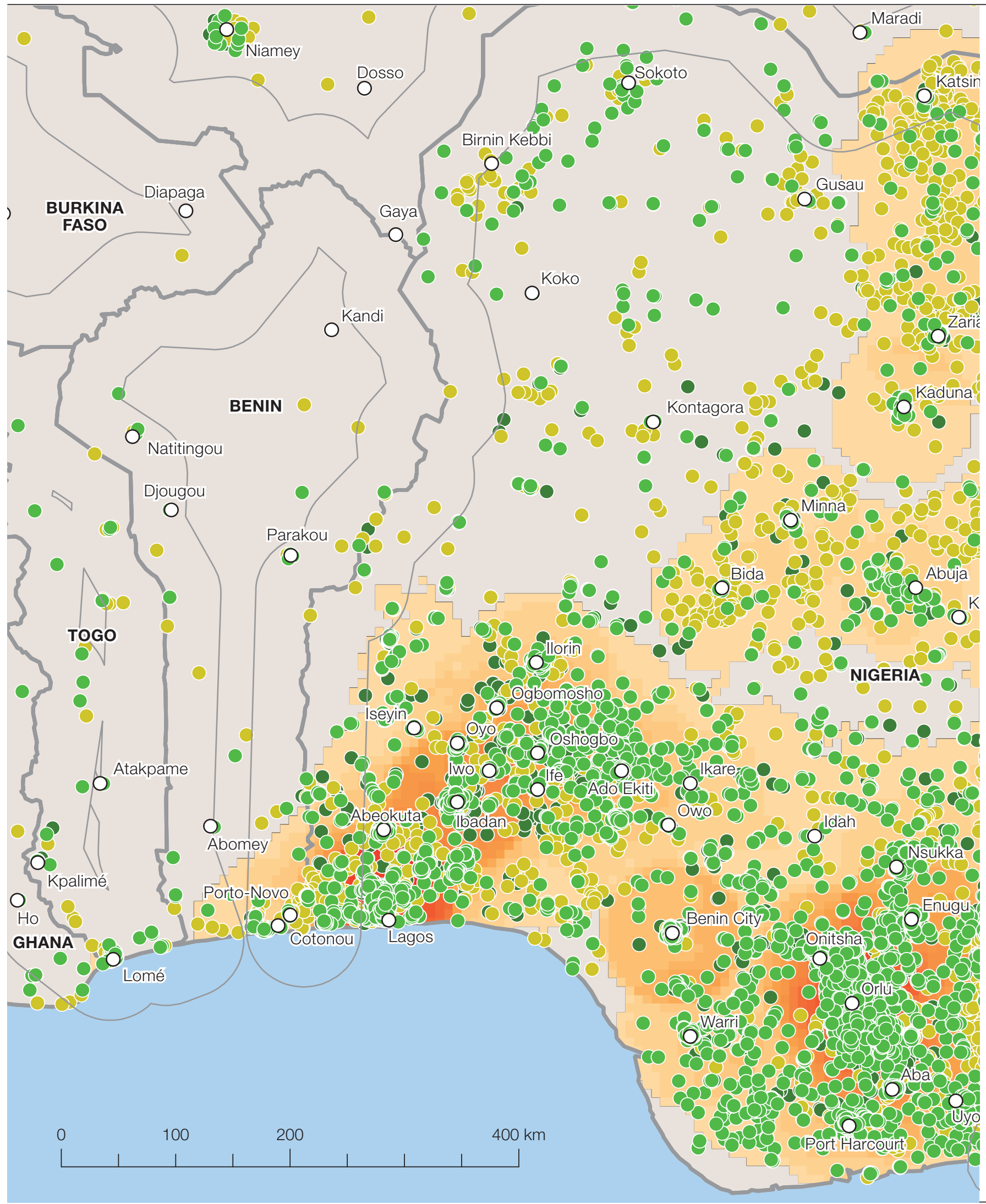

Note: Facilities in Cameroon were not included. Source: Global Healthsites Mapping Project 


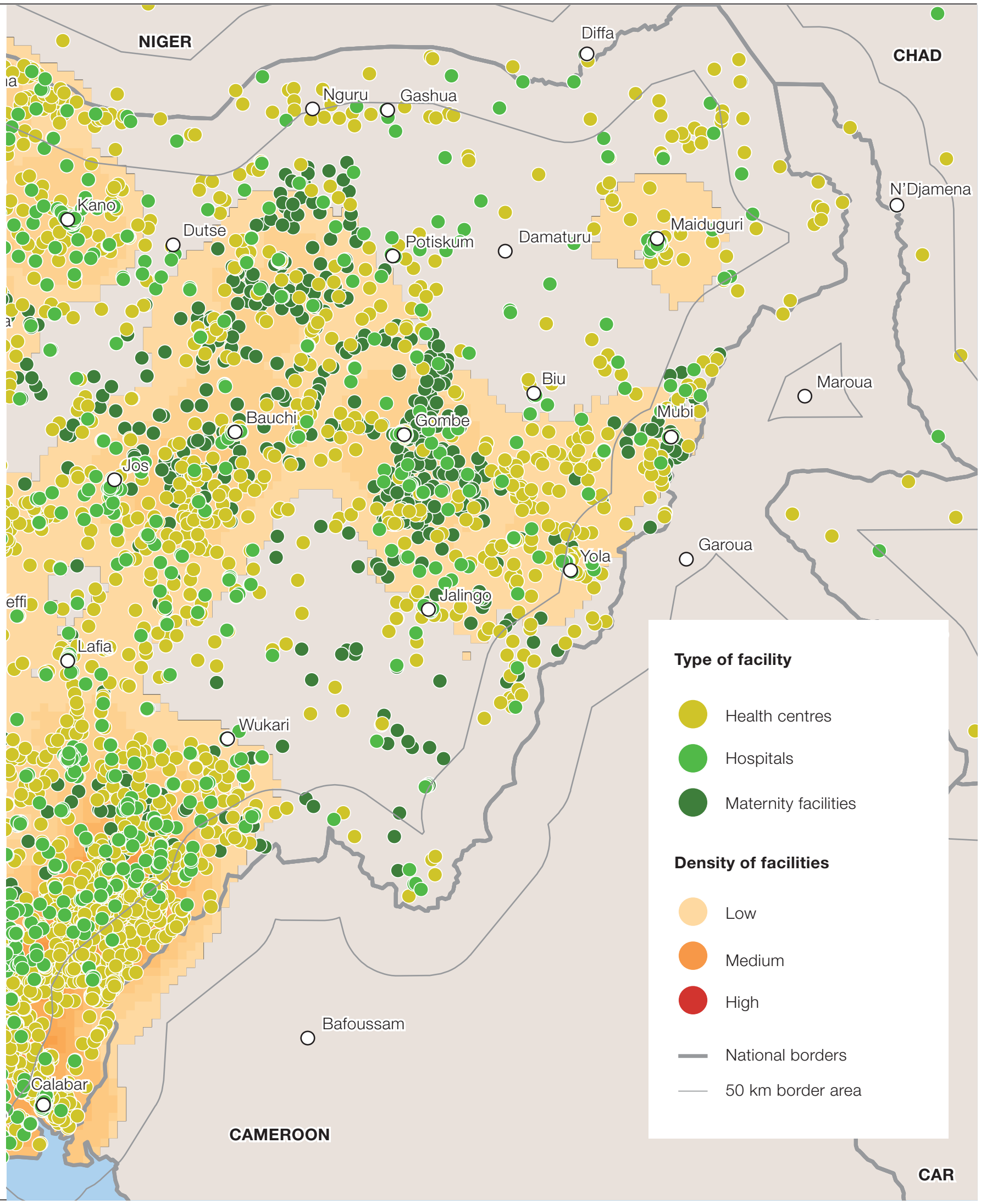




\section{Figure 2.3}

Percentage of health establishments and urban population in relation to distance from a border

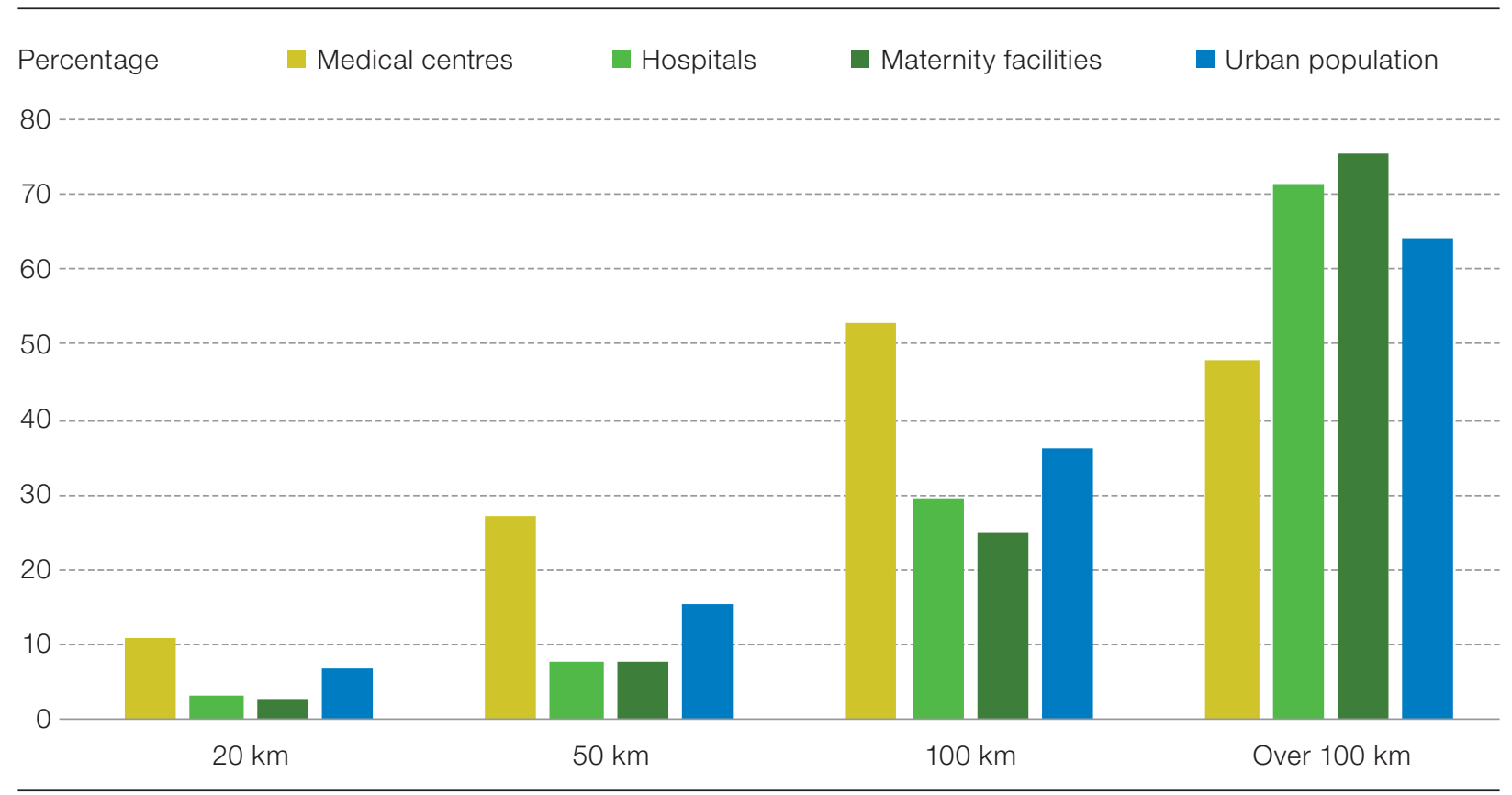

Note: Health infrastructures are counted for 2017 (or nearest year) and the population figures are from 2015. Sources: Global Healthsites Mapping Project and OECD/SWAC 2018

Border regions have a surplus of medical centres and a deficit of hospitals and maternity facilities as compared with urban population size. As such, the percentage of hospital and maternity facility infrastructure is always lower than the percentage of the population living in border region cities (Figure 2.3). At 50 kilometres away, the gap between establishments and the urban population is widest: the respective percentage of hospitals (8\%) and maternity facilities $(7 \%)$ is two times lower than might be expected for the urban population (15\%). Inversely, the interior of West African countries is generally better equipped in terms of top-tier health infrastructure relative to urban population size. The respective percentage of hospitals (71\%) and maternity facilities (75\%) is well above the percentage of the population living in cities $(64 \%)$.

These results suggest there is a health infrastructure deficit of regional scope in border areas, which is especially problematic in areas located less than 50 kilometres from a land border. The 50 kilometres threshold involves a trajectory (as the crow flies) of a maximum of 100 kilometres return, which can represent several hundred kilometres in actual travel and several hours of travel time, especially during the rainy season or when crossing the border involves significant delays. Given the condition of the roads and the lack of ambulances in the region, this threshold may be deemed the theoretical limit at which border populations would be less inclined to seek healthcare in another country. 


\section{Map 2.7}

Ouarokuy-Wanian cross-border health centre

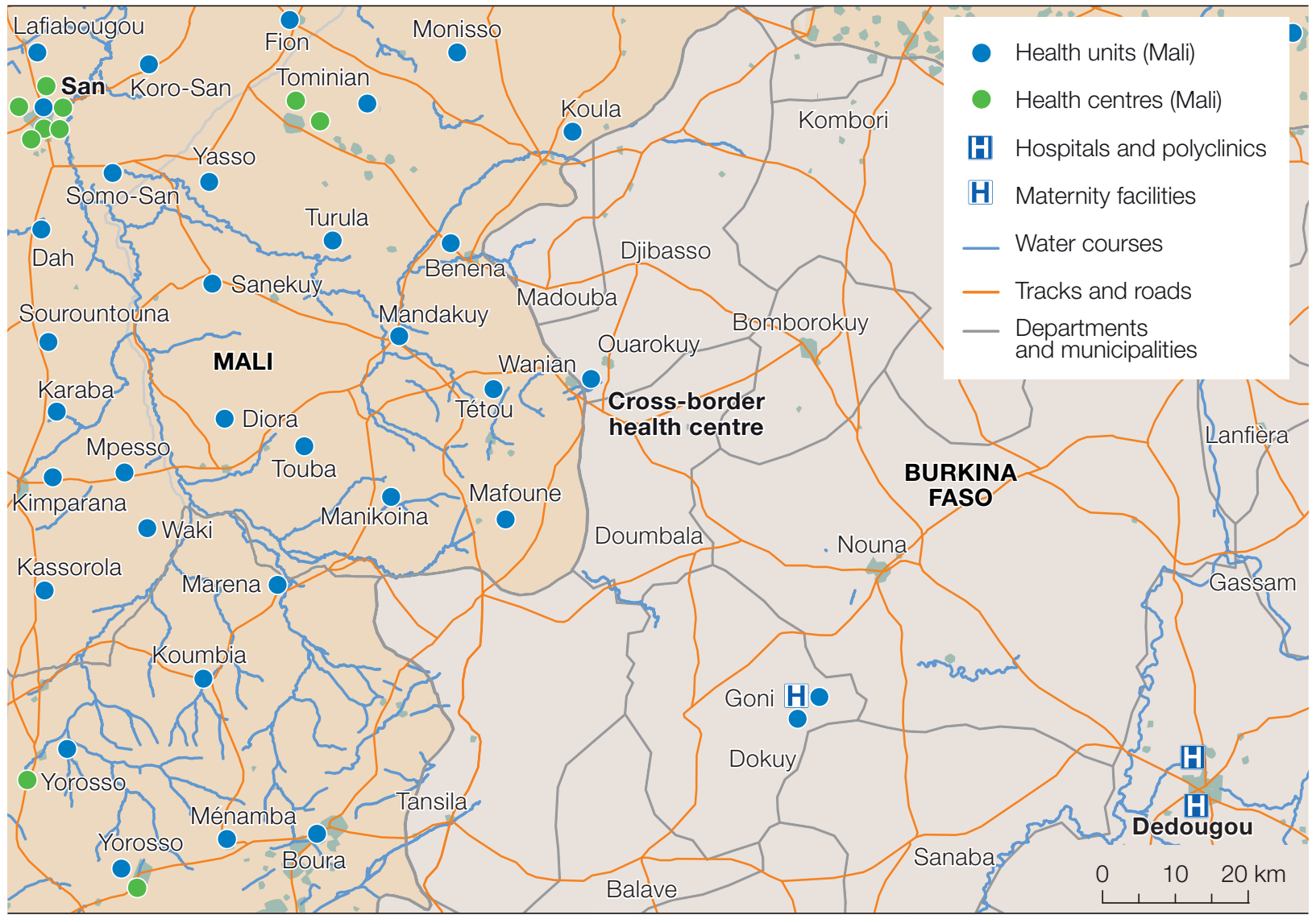

Source: Global Healthsites Mapping Project

\section{Health coverage in the SKBo area}

The region bordered by the cities of Sikasso, Mali; Korhogo, Côte d'Ivoire; and Bobo-Dioulasso, Burkina Faso (SKBo); is an example of the constraints imposed by the uneven geographic distribution of health facilities in West Africa.

The region is often seen as a pioneer of cross-border health co-operation, due to the construction of the Ouarokuy-Wanian cross-border health centre which opened its doors in February 2012 on the border between Burkina Faso and Mali (Map 2.7). The centre was financed by German Development Cooperation through its African Union Border Programme (AUBP) support project. The initiative is one of a kind in Africa, in terms of its consensus-based design and approach to management which includes representatives of local and regional governments of both countries. The health centre has helped improve health coverage in the region, which is located over 300 kilometres from Ouagadougou and 400 kilometres from Bamako, as the crow flies. At a cost of less than one-half million euros, it includes a dispensary, a maternity 
ward, a pharmaceutical depot as well as accommodations and administration buildings. In its first year of operations, the two health officers hired by the national governments on either side of the border provided health services to about 5000 patients from both countries (Tapily, 2017).

A cross-border group for health co-operation between the municipality of Djibasso in rural Burkina Faso and the municipalities of Mafouné and Mandiakuy in rural Mali was established to manage the construction of the health centre in Ouarokuy-Wanian, which was built in Burkina Faso. More recently, a local cross-border co-operation group (LCCG) was established by Burkina Faso municipalities in the province of Kossi and the Cercle de Tominian municipalities in Mali; it brings together some 225000 people to strengthen local governance in the region. The LCCG's legal capacity and budgetary autonomy was developed by local and regional governments together with European Union public bodies, in accordance with the Karlsruhe Agreement signed by Germany, France, Luxembourg and Switzerland in 1996.

A number of challenges exist in the region where the Ouarokuy-Wanian centre was built. Low populations densities, a lack of large urban centres and an underdeveloped road network limits all types of travel, including for medical emergency purposes. To remedy the situation, the local crossborder co-operation programme - established by UEMOA's council of local government authorities and backed by the Swiss Agency for Development and Co-operation - plans to offer a wide range of medical services to patients in both countries and improve the cross-border mobility of goods, people and services (UEMOA, 2017a). Plans for labour-intensive initiatives have been developed to build 26 kilometres of tracks to link the region's villages to the health centre; fifty or so wastewater facilities and watercourse crossings will also be put in place along the tracks.

The sparse human settlement pattern in the Ouarokuy-Wanian region is typical of border areas located between Burkina Faso, Côte d'Ivoire and Mali, from Ouahigouya to Bougouni (Map 2.8). The region is located between the Mossi centre of settlement in the east, the densely populated Bani and Niger River valleys in Mali to the north and west and the Korhogo basin in Côte d'Ivoire to the south. While there are at least ten border markets in the area, few large cities are located in immediate proximity to the borders, with the exception of Sikasso. Further west, in the direction of Guinea, the lack of cities and roads is even more apparent.

These human and physical constraints have fostered the development of an Integrated Transboundary Development Scheme (SATI) for the SikassoKorhogo-Bobo-Dioulasso (SKBo) region as part of the UEMOA's PCTL (UEMOA, 2017a). It is based on the results of several studies conducted in the region by partners since the mid-2000s (OECD/SWAC, 2003; Enda Diapol, 
2007; and Alvergne, 2007) in order to better understand cross-border interactions and local governance.

The SATI makes note of the transport problems and weak urban framework particularly in western Baoule - which limits access to public services; it also points to the limited urban services offered due to lack of equipment in small- and medium-sized cities. Remedying this situation will involve significant road upgrades in the coming decades on both the north-south routes often used by transport companies to supply Bamako and between the eastern and western parts of the region (UEMOA, 2017a). In addition, SATI foresees local projects aimed at ameliorating rural tracks and urban centres such as Tengréla.

From a health perspective, the Sikasso-Korhogo border region between Mali and Côte d'Ivoire (Map 2.9) helps expose the difference between the health coverage provided by health units and that of more substantial infrastructure. The network of health units (in light green) is quite dense and does not show significant differentials between countries: from Filamana and Tienko in the west to Zégoua and Nielle in the east, not one health unit is further than 25 kilometres, as the crow flies, from another health unit or larger facility. However, the distribution of health centres (in dark green), maternity facilities and hospitals (marked with an upper-case $\mathrm{H}$ ) is clearly more uneven as it is based on the location of major urban centres in the region. In Mali, only the city of Sikasso has health infrastructure of regional scope, while six cities located between 50 and 150 kilometres away from each other have hospitals and maternity wards on the Côte d'Ivoire side of the border, including the hospital in Tengréla, which is located less than 10 kilometres from Mali. This uneven health coverage points to the need for putting in place health infrastructure to be shared by cities and regions in different countries.

\section{Border cities central to health co-operation}

The Ouarokuy-Wanian health centre is an exception in West Africa, where few health initiatives are specifically designed to serve people living in a neighbouring country. Each country in the region distributes its health facilities based on its financial capacity, and with a view to serving the entire national population without explicitly considering international patients. The limits of this national healthcare planning have long been a concern for some West African countries, regional organisations and their international partners. As far back as 2000, the President of Mali, Alpha Oumar Konaré, noted that the process of regional integration would involve establishing areas where people could avail of common schools, security posts, markets and health centres. Along the same lines, the ECOWAS Memorandum on pays-frontière makes the following recommendation: "implement an integrated public health programme improving access to health care by populations on both sides of the border" (ECOWAS, 2005: 3). 


\section{Map 2.8}

Population densities in Burkina Faso, Côte d'Ivoire and Mali, 2014

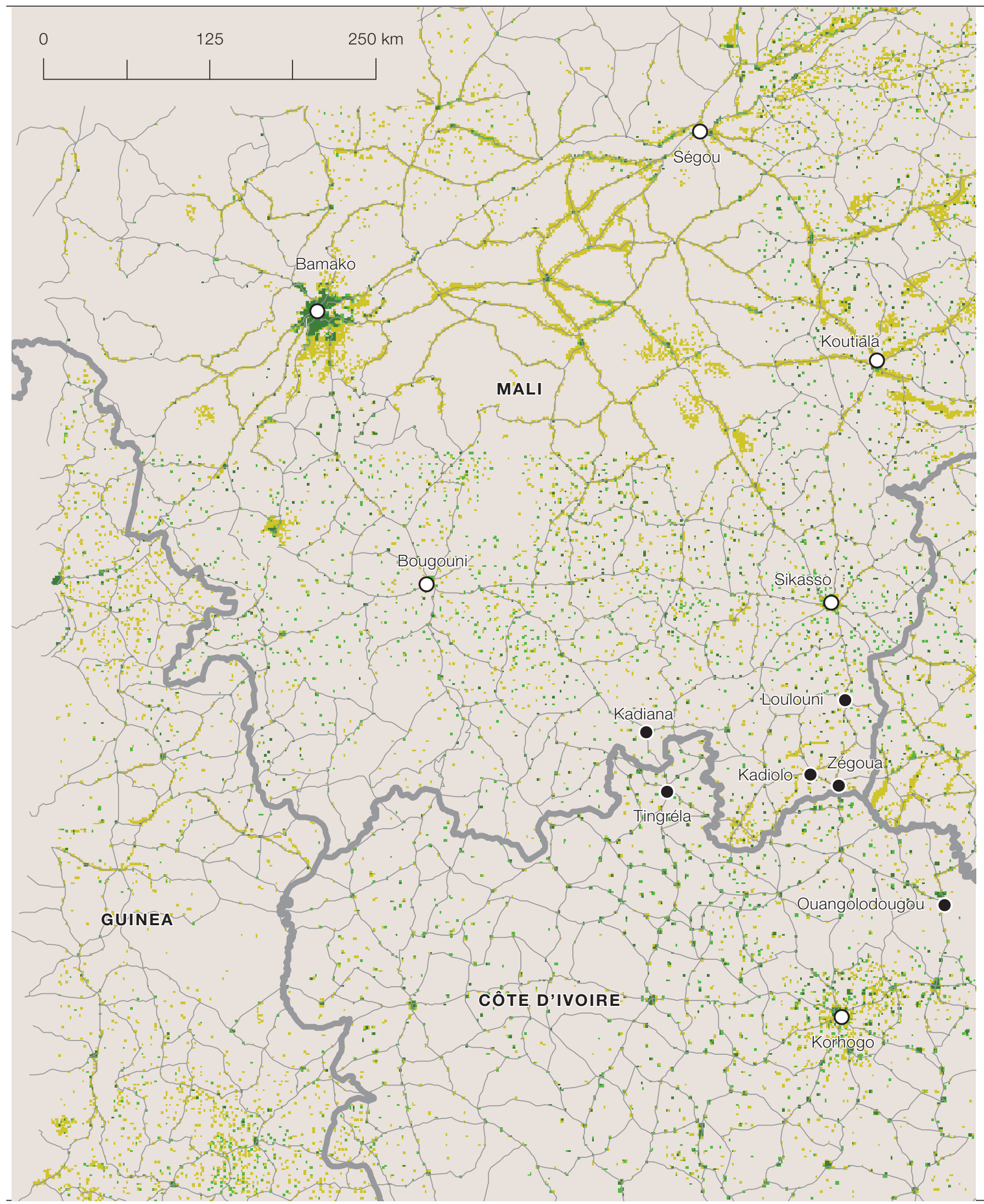

Sources: CILSS, 2017; European Space Agency, 2010; Global Administrative Areas, 2018; Global Roads Open Access Data Set, 2018; LandScan TM, 2014; NASA, 2014; OpenStreetMap, 2018; OECD/SWAC, 2018; Wageningen Environmental Research (Alterra). 


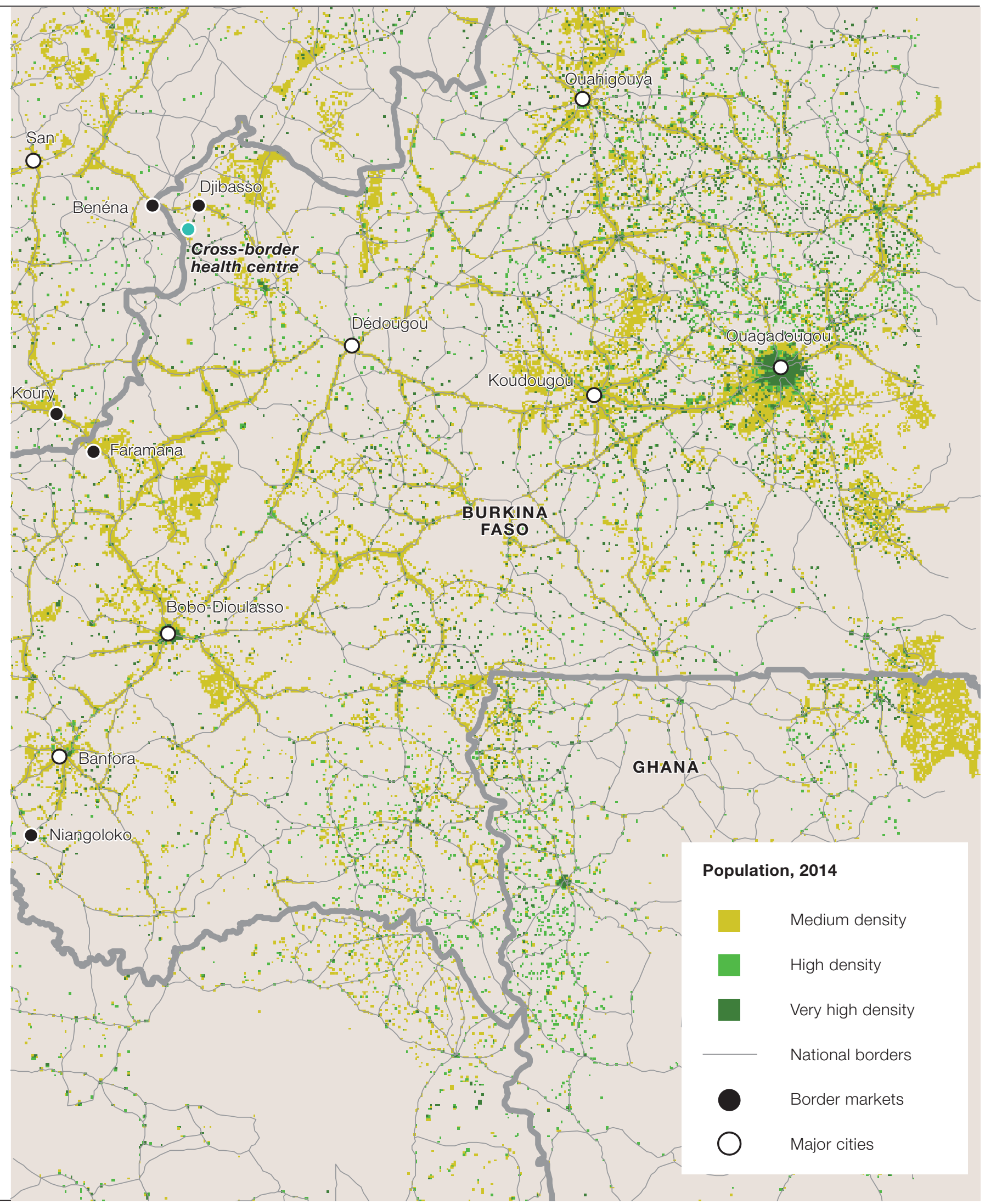




\section{Map 2.9}

Health facilities in Mali and Côte d'Ivoire, 2017

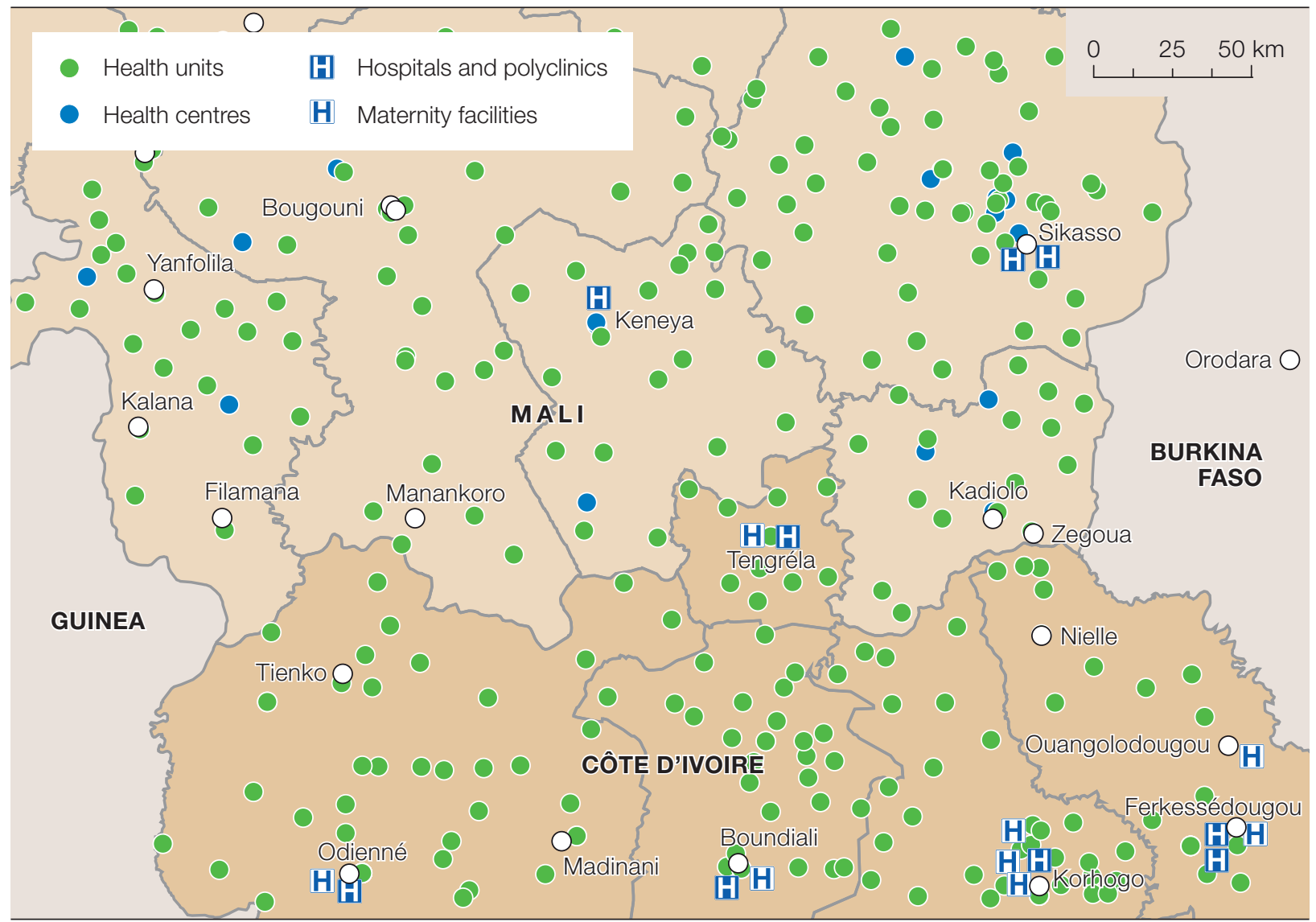

Source: Global Healthsites Mapping Project

There are two quite different approaches to establishing cross-border health facilities. The first consists of identifying the regions where health infrastructure is lacking and putting health centres in place in locations where there are none. For example, the decision to build cross-border infrastructure to serve Ouarokuy and Wanian was made following a 2006 conflict related to natural resource management involving border communities. The reconciliation process undertaken under the aegis of elected municipal officials resulted in local populations identifying health as a priority area for investment in the region.

The second approach consists of strengthening existing infrastructure by providing some health units in border areas with more specialised medical equipment and personnel. It also relies on field surveys to identify the facilities more regularly visited by patients from a neighbouring country. This option was suggested by the United Nations Capital Development Fund's (UNCDF) Local Cross-Border Initiative (LOBI) programme in the LiptakoGourma region. The program also notes, for example, that the health centres in Labbezanga, Mali; Tin Akoff, Burkina Faso; and Petelkolé-Chatoumane, 
Niger; could "be subject to technical upgrades to become true cross-border referring centres” (UNCDF, 2017: 40).

Both approaches assume that cross-border infrastructure serves a larger population base than that identified by national health systems. Border populations' accessibility to health infrastructure depends on a number of factors, including the existence of quality transportation networks as well as a lack of delays in crossing borders and conducting roadside checks (see West African Papers no. 23). By superimposing data on the population of cities with more than 10000 inhabitants located less than 20 kilometres for a border onto the data on health facilities, it is possible to identify several regions where health services could be improved through closer collaboration between the countries in the region. Only top-tier facilities such as health centres, hospitals and maternity facilities were taken into consideration, insofar as they have the potential to serve a cross-border population.

In Senegambia, the border differentials are especially significant in terms of health services (Map 2.10). In the Senegal River region, most high-level health facilities are located on the Senegalese side of the river, while on the Mauritanian side there are almost none from Rosso to Bakel at 20 kilometres from the border. This asymmetry is made even more problematic by the fact that there are very few roads crossing between the two countries, which considerably limits the theoretical population base of border cities. Along the Gambia River, most health infrastructure is located in Gambia rather than Senegal. Road access between the two countries is better than in the Senegal River valley, in particular to the north, toward Kaolack, which increases the number of people that could potentially be reached from the border. In the eastern part of the region, cities in Mali close to the border separating Mali from Mauritania, from Kersigagne to Kirane, lack health centres and hospitals of regional scope.

In Liberia and Sierra Leone, the effective health coverage is lower than the map of health facilities suggests (Map 2.11). The healthcare systems in these countries are in a serious state of deterioration, in fact, many facilities classified as health centres are in reality units with very basic equipment. Given that fact, it appears that large sections of Sierra-Leone's borders do not have the equipment needed to serve as regional facilities. The only hospitals listed are located in the Kambia border area, north of Freetown. On the other hand, the health coverage in Fouta Djalon is denser, especially between Guéckédou, Guinea; and Ganta, Liberia. However, the mountainous landscape and relative rarity of transport routes reduces the theoretical population base of the cities. The outbreak of the Ebola fever epidemic in the region from 2014 to 2015 also served as a dramatic reminder of the urgency of rebuilding healthcare systems capable of responding to cross-border crises after several decades of structural adjustment programmes and civil wars (Abdullah and Rashid, 2017). 


\section{Map 2.10}

Senegambia's health facilities and population base

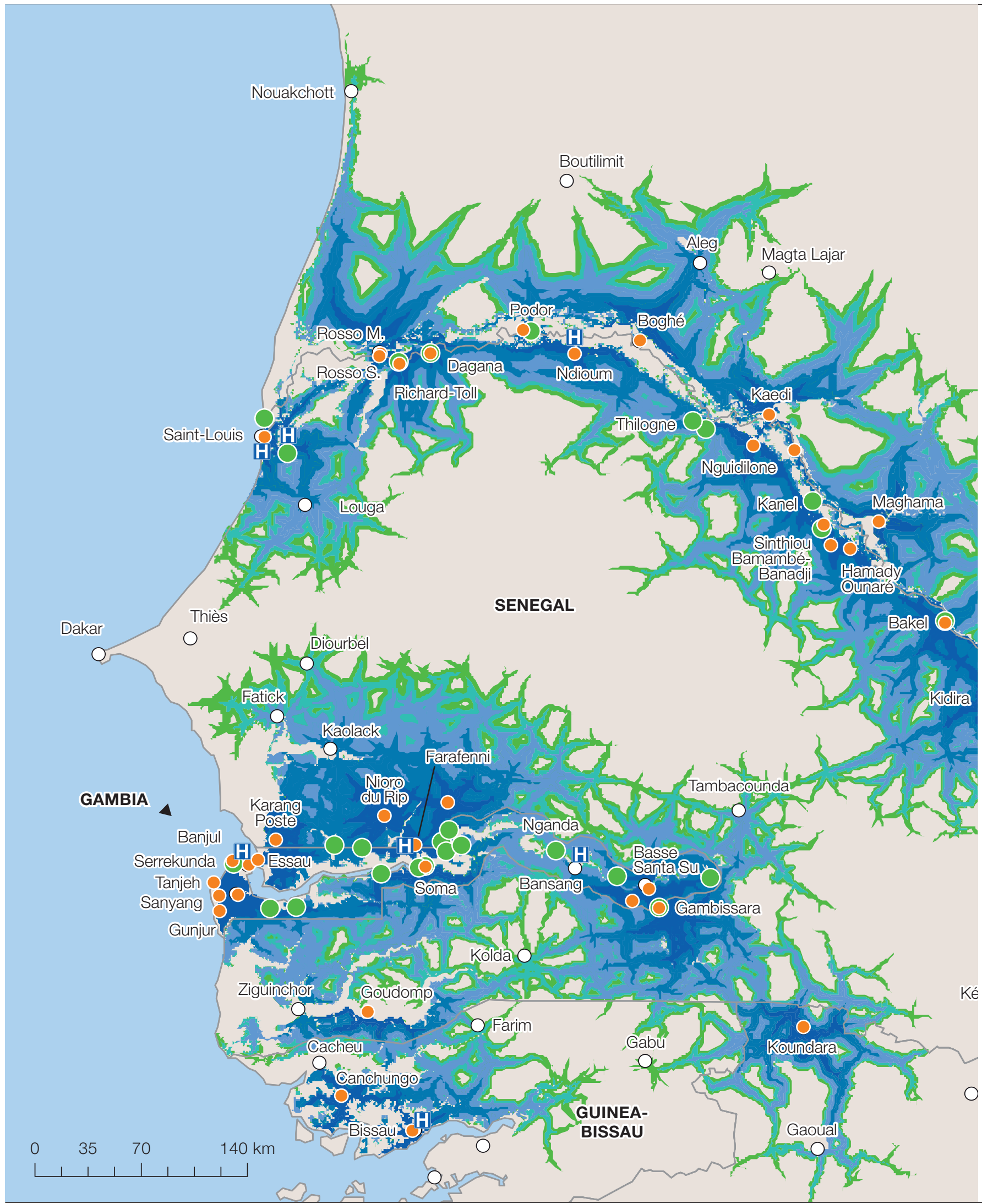

Note: Health units were not included.

Source: Global Healthsites Mapping Project 


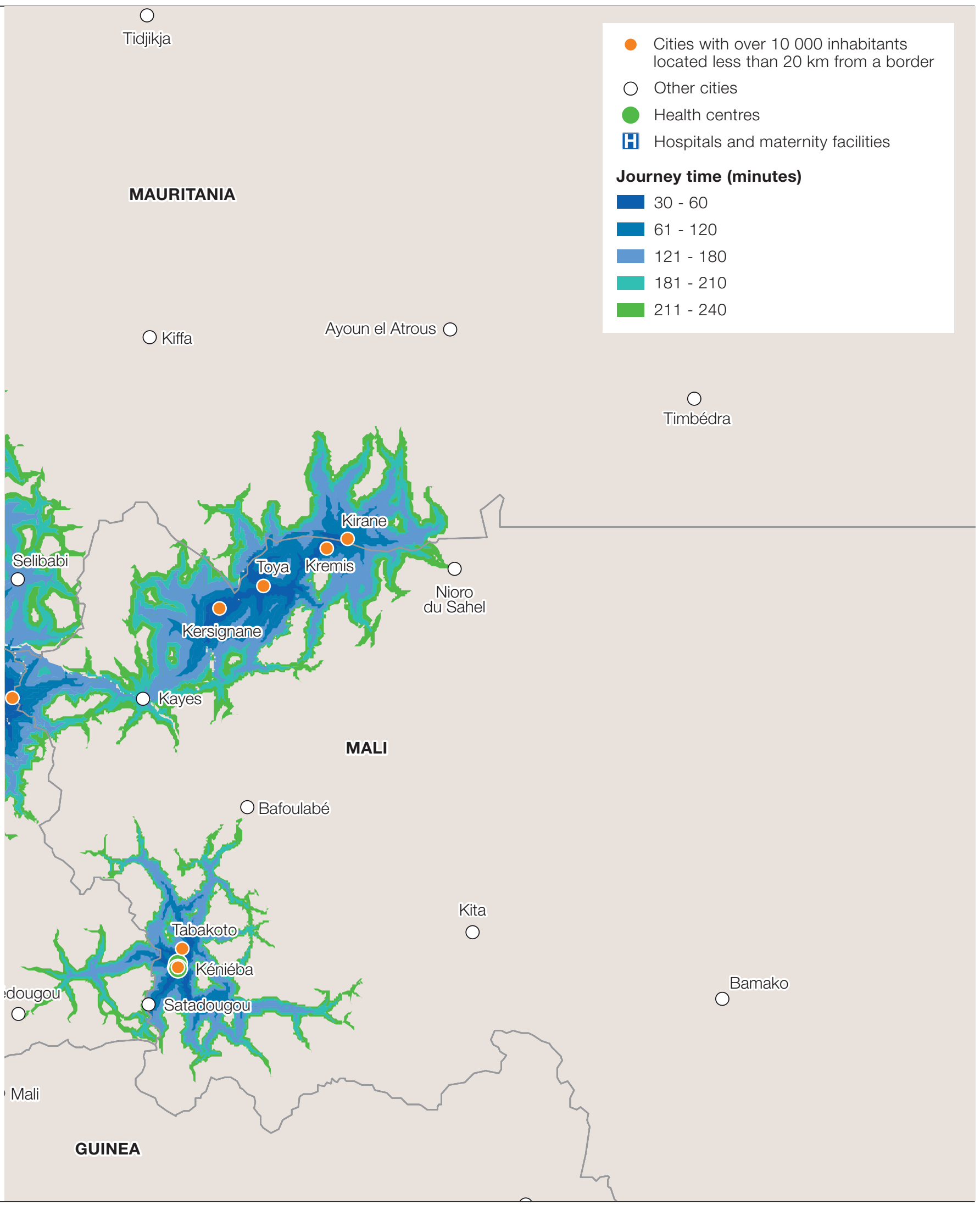




\section{Map 2.11}

Health facilities and population base in the western Gulf of Guinea

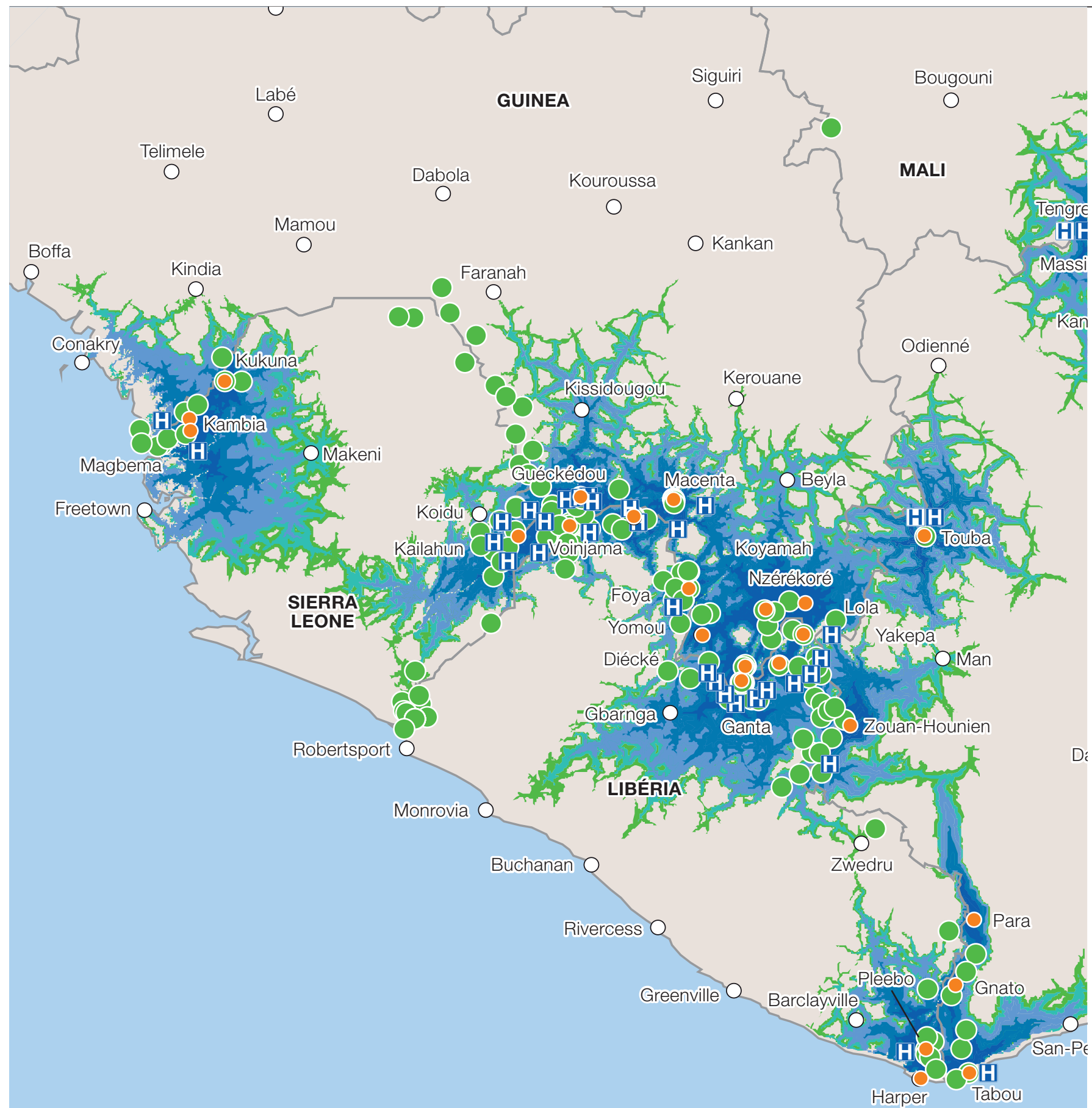

Note: Health units were not included. 

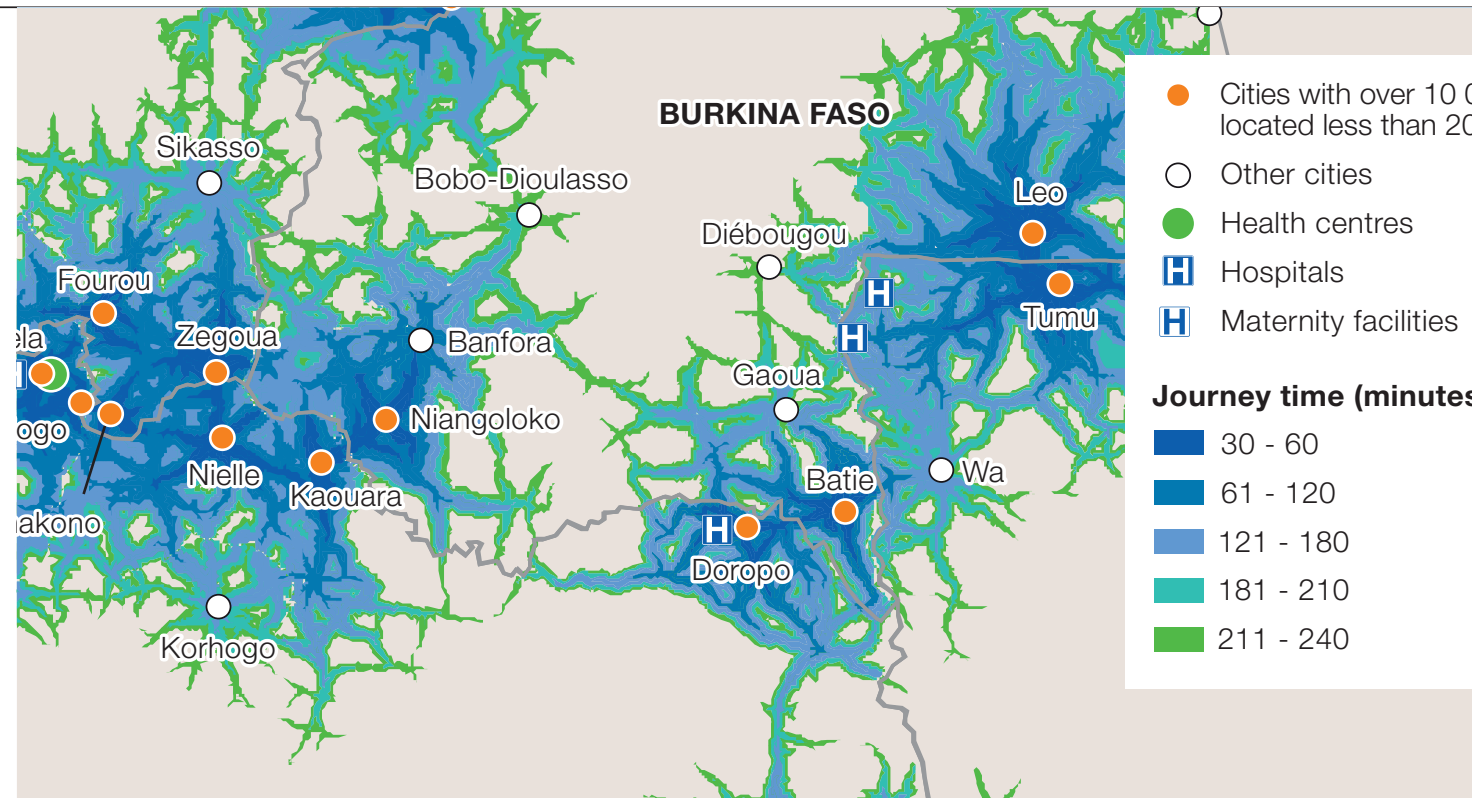

CÔTE D'IVOIRE

○

Yamoussoukro

Bouaké

O

aloa

$\bigcirc$
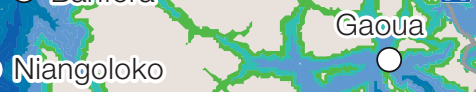

\section{Journey time (minutes)}

$30-60$

$61-120$

$121-180$

$181-210$

$211-240$
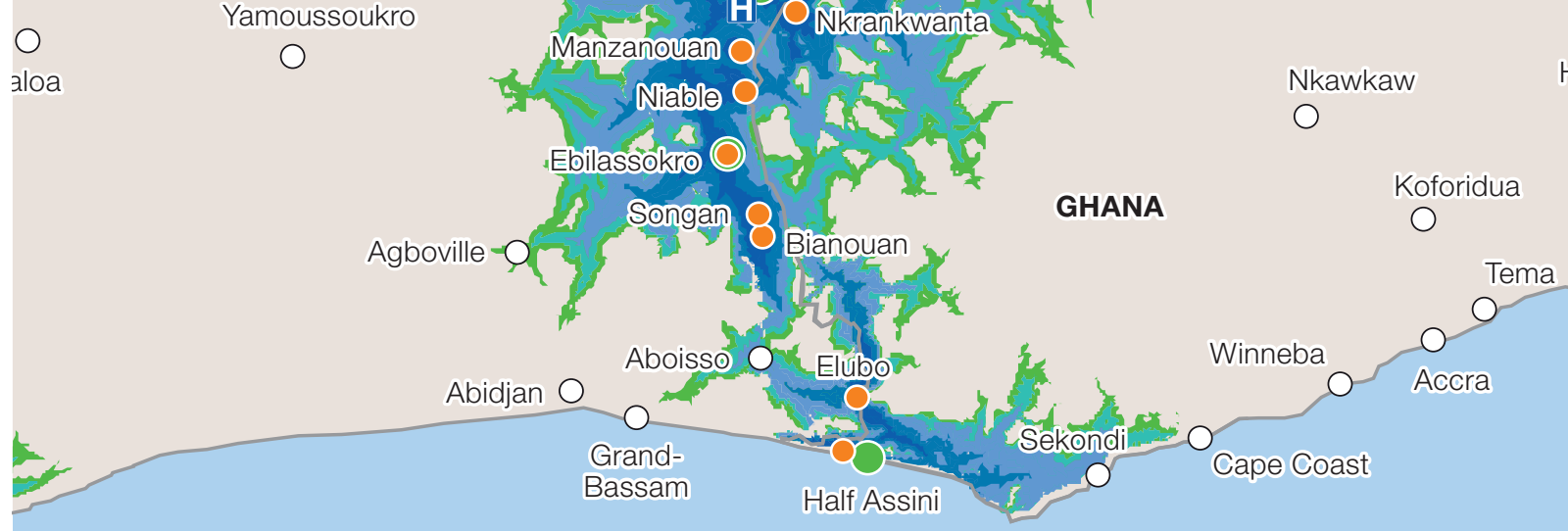

GHANA

O

Koforidua

$\mathrm{O}$

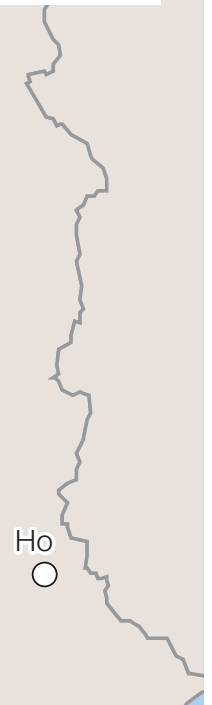

ma

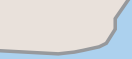

dro

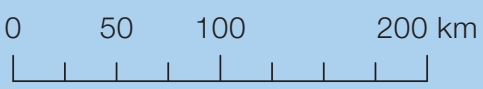


Further east, the Sikasso/Korhogo/Bobo-Dioulasso triangle features very low levels of health coverage in areas near a border. The top-tier health facilities are located in regional urban centres in Burkina Faso, Côte d'Ivoire and Mali (Map 2.9). A lack of hospitals and health centres was also noted on the border between Côte d'Ivoire and Ghana and between Bondoukou and Elubo, where are more than a dozen border cities are located. There is also a deficit of top-tier facilities on the section of border between Ghana and Togo from Hohoe in the south to Dapaong in the north, as well as in the northernmost part of Togo (Map 2.12). Few health facilities were noted near the Burkina Faso sections of the borders.

The most remarkable feature on Benin's borders is the strong dichotomy between the southern part of the country, which is well equipped as far as Abomey, and the rest of the nation. This situation is due in part to the fact that half of the country's population lives in the Cotonou/Porto Novo metropolitan region, which had a population of 5.4 million people in 2015, whereas the northern part of the country is relatively rural. The existence of large urban centres located in close proximity to a border, such as Cotonou and Lagos, combined with high population, result in the largest population bases in West Africa. Here, where accessibility by road and the density of health facilities is the highest in the region, the need for cross-border co-operation is, consequently, the lowest.

Further north, healthcare availability and accessibility by road are better throughout Nigeria than in Niger (Map 2.13). Most health centres and hospitals of regional scope are located in Nigeria, from Kamba in the west to Diffa in the east (facilities in Cameroon were not mapped). The region's population bases is the largest in West Africa after the eastern Gulf of Guinea; this is due to the large number of cities, the relatively obstacle-free terrain and the density of Nigerian road networks. The asymmetry of health services between Niger and Nigeria favours the implementation of cross-border co-operation between the two countries.

Enhancing cross-border health co-operation is a priority that no government in the region can ignore. It will involve constructing or retrofitting facilities located within immediate proximity of a border. The combined analysis of existing health services and the population base of cities in which some facilities have the potential for cross-border influence, can be used to identify some regions that would benefit from more deeply integrated healthcare systems. This is the case in the Senegal River valley, western Mali, Fouta Djalon, the SKBo area, eastern Côte d'Ivoire, northern Togo and on the Niger-Nigeria border, where a general lack of health facilities and/or an uneven distribution of them between the two countries can be observed.

Putting health facilities in place presupposes that legal and institutional solutions are found to foster mobility between national healthcare systems. 
This poses a significant challenge, as witnessed by the problems encountered during the process of integrating European systems (Wismar et al., 2011). In West Africa, this objective is all the more pressing due to the highly mobile population, the existence of cross-border epidemics and pathogens as well as under investment in public health infrastructure. 


\section{Map 2.12}

Health facilities and population base between Togo and Benin

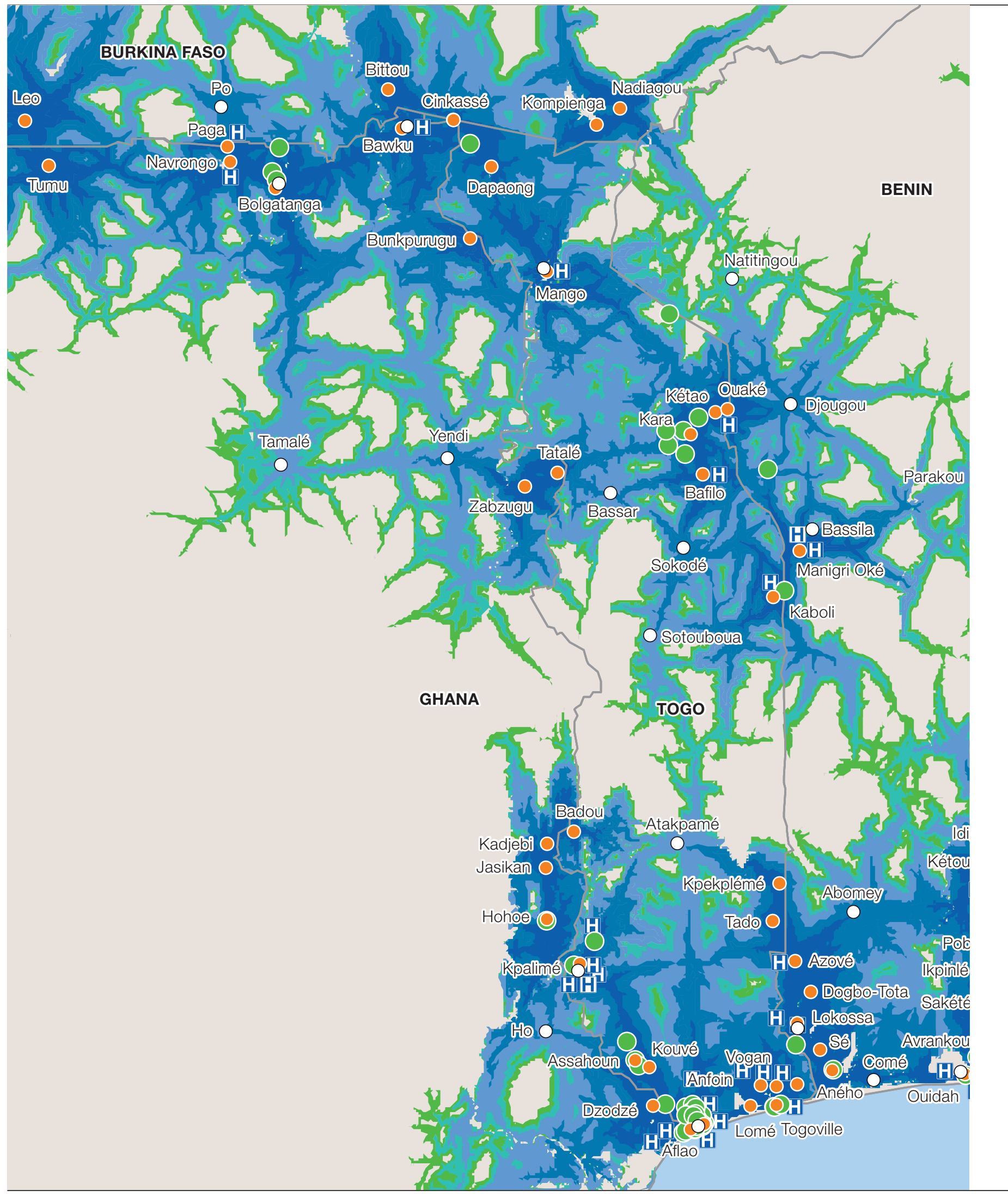




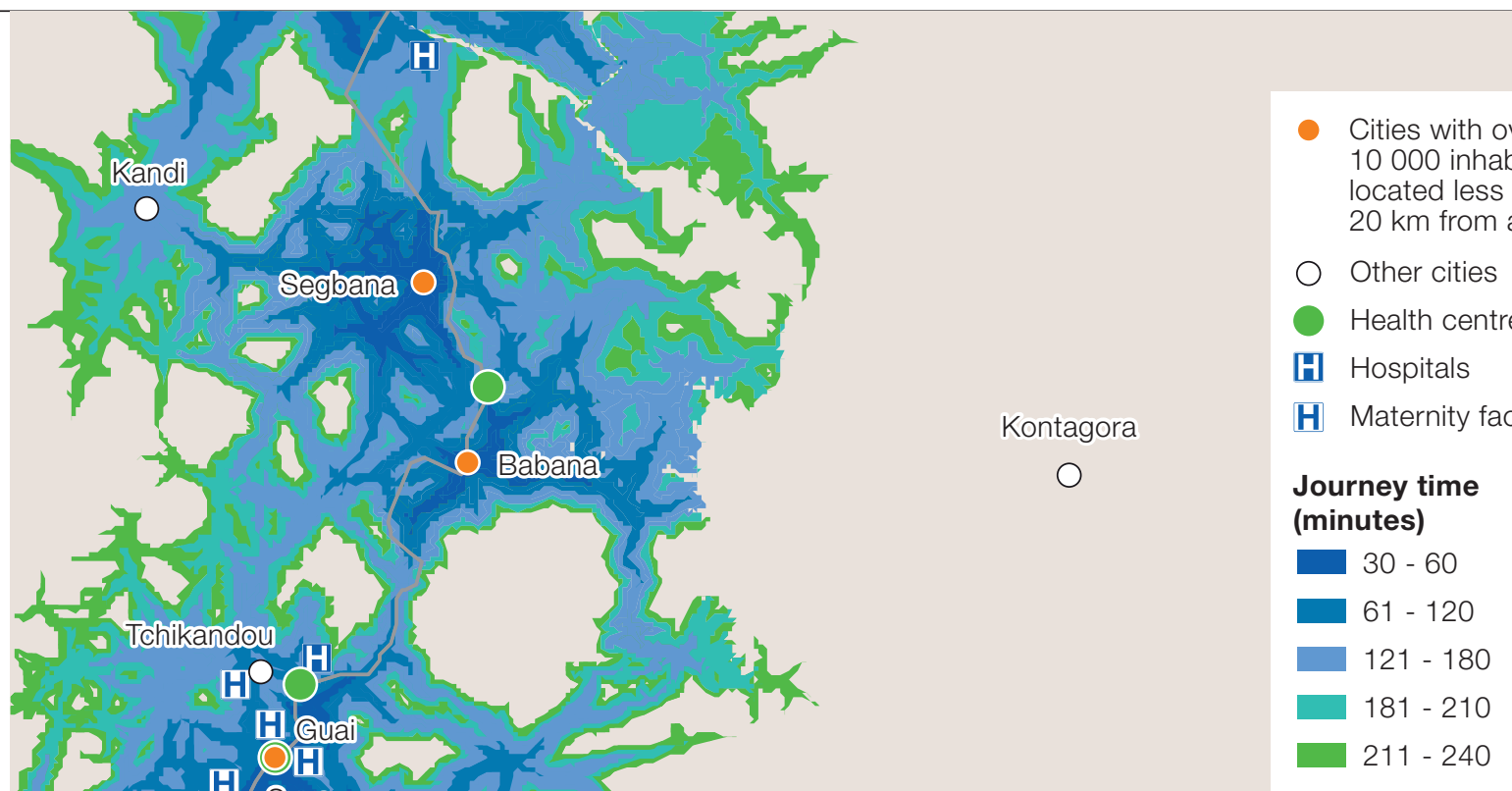

NIGERIA

Ado Ekiti

O

Owo 0

Benin City $\mathrm{O}$ 


\section{Map 2.13}

Health facilities and population base in Nigeria

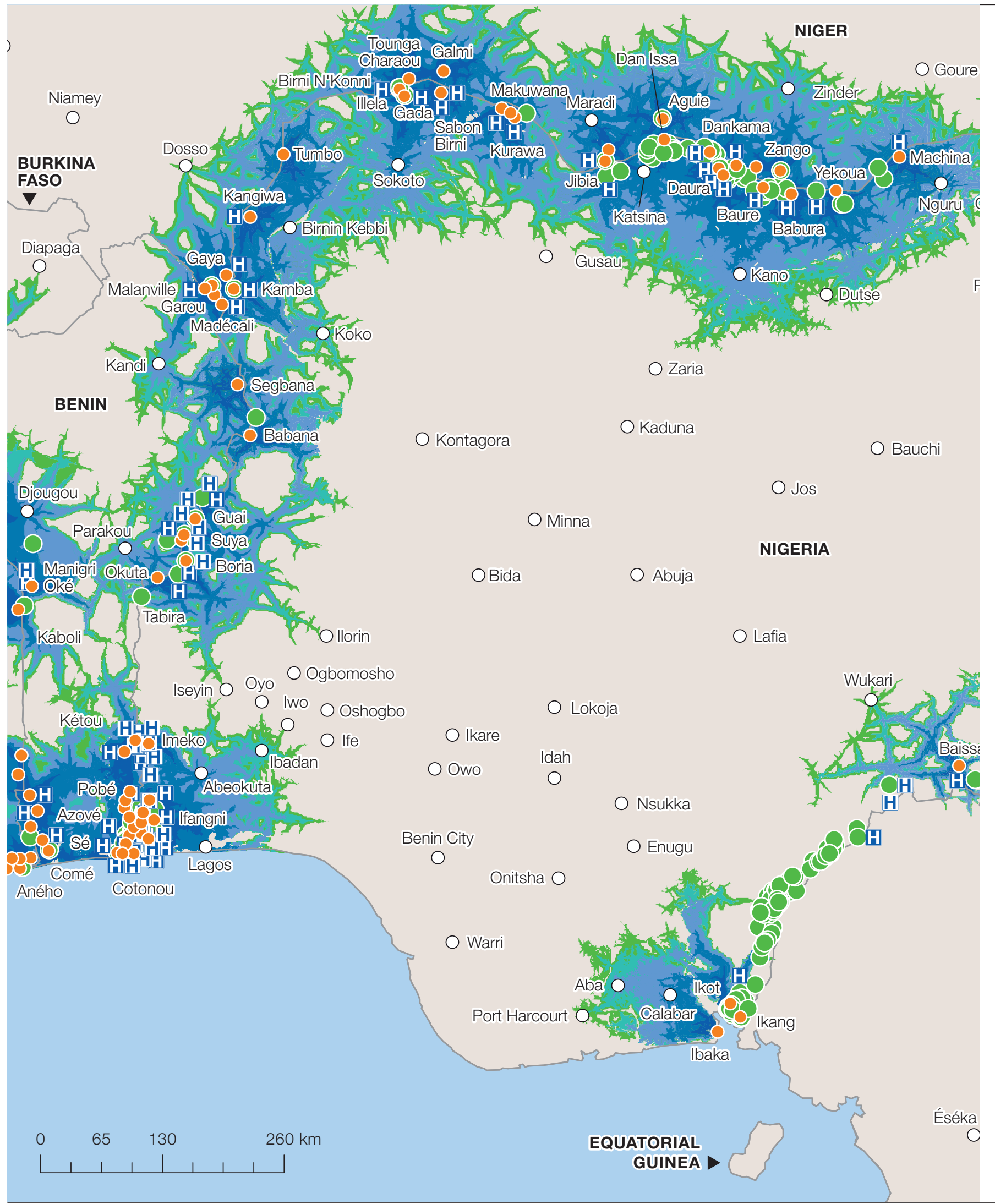

Note: Health units in the region and facilities in Cameroon were not included. Source: Global Healthsites Mapping Project 


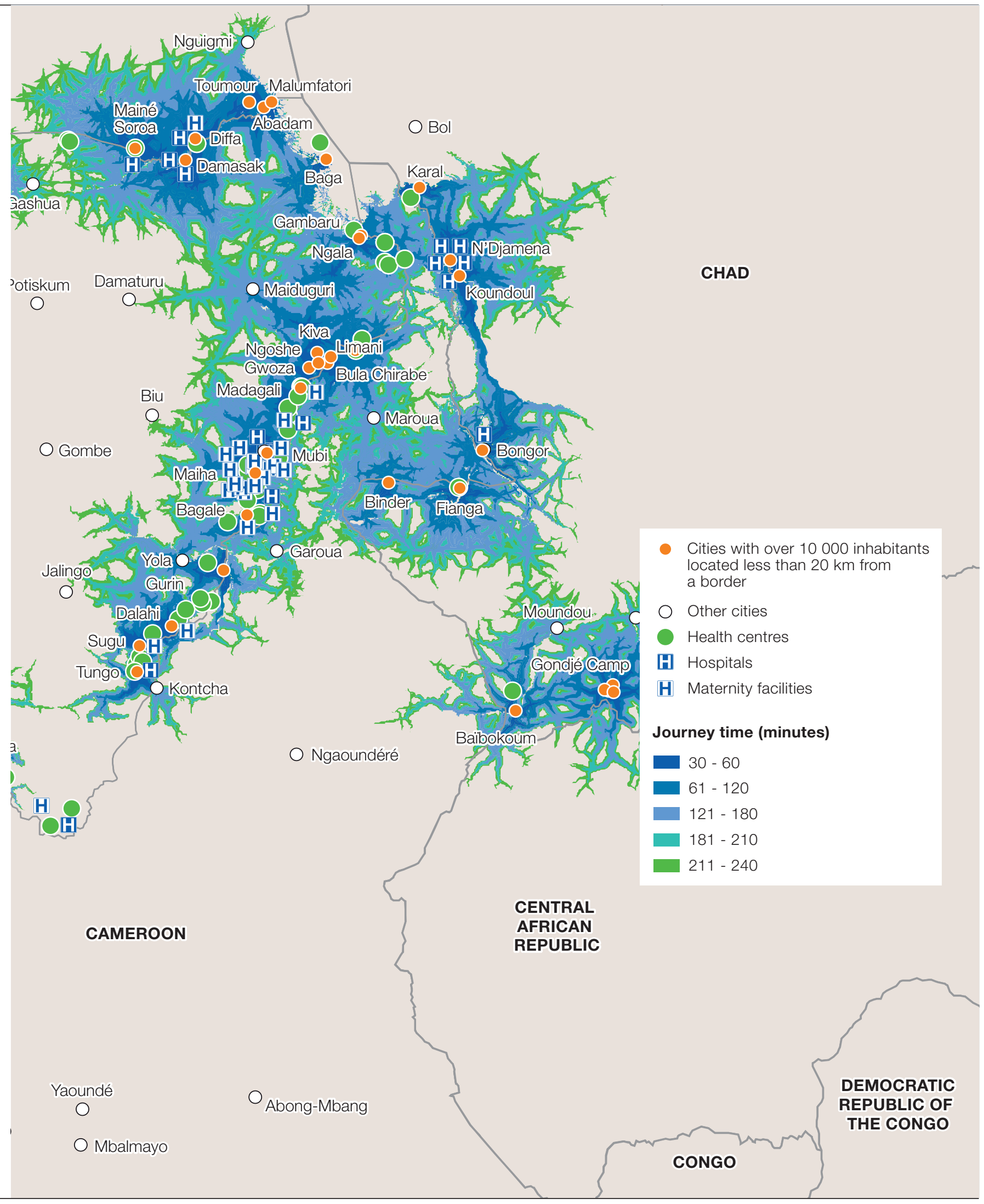




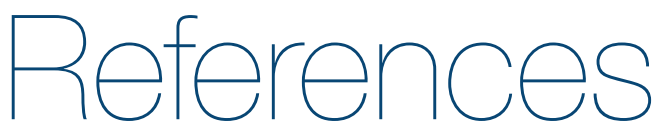

Abdullah I and I. Rashid (eds.) (2017), Understanding West Africa's Ebola Epidemic. Towards a Political Economy, Zed, London.

ADB/OECD/UNDP (2015), African Economic Outlook, Regional Development and Spatial Inclusion, OECD Publishing, Paris, https://doi.org/10.1787/19991029.

Alvergne, C. (2007), "Quelles politiques territoriales pour inscrire l'Afrique dans la mondialisation?”, Les Cahiers d'Outre-Mer, No. 238, pp. 203-216.

ApiMali (2017), Agence pour la promotion des investissements au Mali, 2017 data.

Bertrand, M. (2015), "Du District au " grand Bamako » (Mali) : réserves foncières en tension, gouvernance contestée”, Cybergeo: European Journal of Geography, https://doi.org/10.4000/cybergeo.27383.

Boilley, P. (1996), Les Touaregs Kel Adagh, Karthala, Paris.

Debrie, J. (2010), "From colonization to national territories in continental West Africa: the historical geography of a transport infrastructure network", Journal of Transport Geography, Vol. 18, No. 2, pp. 292-300.

ECOWAS (2005), Cross-border Initiatives Programme 2006-2008, OECD/SWAC, Paris, https://www.oecd.org/swac/publications/38447562.pdf.

Enda Diapol (2007), Les dynamiques transfrontalières en Afrique de l'Ouest, Karthala, Paris.

Global Administrative Areas (2016), GADM database of Global Administrative Areas GADM 2.8, https://protect2.fireeye.com/url?k=2fac6b17-73b7229f-2fac40d4-002590f45c8823a6e17d54c9b376\&u=http://www.gadm.org/.

Global Health Site Mapping Project, https://healthsites.io.

Global Roads Open Access Data Set (2016), Global Roads Open Access Data Set, Version 1 (gROADSv1), NASA Socioeconomic Data and Applications Center (SEDCAC); Center for International Earth Science Information Network (CIESIN), Columbia University; and Information Technology Outreach Services (ITOS), University of Georgia, https://doi.org/10.7927/H4VD6WCT.

Golding, N. et al. (2017), "Mapping Under-5 and Neonatal Mortality in Africa, 2000-15: A Baseline Analysis for the Sustainable Development Goals", The Lancet, Vol. 390, No. 10108, pp. 2171-2182.

Grégoire, E. (2013), "Islamistes et rebelles touaregs maliens : alliances, rivalités et ruptures”, EchoGéo, https://doi.org/10.4000/echogeo.14933.

Herbst, J. (2014), States and power in Africa: Comparative lessons in authority and control, Princeton University Press, Princeton.

Herbst, J. (2000), States and power in Africa: Comparative lessons in authority and control, Princeton University Press, Princeton.

IMF (2017), Regional economic outlook: Restarting the growth engine, International Monetary Fund, Washington DC.

LandScan TM Global Population Database (2014), Global Population Database, Oak Ridge National Laboratory, Oak Ridge.

Lovejoy, P.E. (1980), Caravans of kola: the Hausa kola trade, 1700-1900, Ahmadu Bello University Press, Kano.

Magrin G., J. Lemoalle J and R. Pourtier (eds.) (2015), Atlas du lac Tchad, Passages, Paris.

OECD (2018), OECD Employment Outlook, OECD Publishing, Paris.

OECD/SWAC (2019), Africapolis: Urbanisation dynamics in Africa, West African Studies, OECD Publishing, Paris (forthcoming).

OECD/SWAC (2018), Africapolis (database), www.africapolis.org.

OECD/SWAC (2003), Towards a Better Regional Approach to Development in West Africa: Conclusions of the Special Event of Sahel and West Africa Club, May 2002, OECD Publishing, Paris, https://doi.org/10.1787/9789264176270-en.

Oliete Josa, S. and F. Magrinyà (2018), "Patchwork in an interconnected world: the challenges of transport networks in Sub-Saharan Africa », Transport Reviews, pp. 1-27. 
Open Street Map (2014), "Roads", Sutton Coldfield, Open Street Foundation, www.openstreetmap.org.

Osgood-Zimmerman, A. et al. (2018), "Mapping Child Growth Failure in Africa between 2000 and 2015”, Nature, Vol. 555, No. 7694.

Taaffe, E.J., R.L. Morrill and P.R. Gould (1963), "Transport expansion in underdeveloped countries: a comparative analysis”, Geographical Review, Vol. 53, No. 4, pp. 503-529.

Tapily, M. (2017), Les périphéries nationales au centre de l'intégration africaine: Le Centre de santé transfrontalier Ouarokuy-Wanian, German Agency for International Cooperation and African Union Border Programme.

UEMOA (2017a), Schéma d'aménagement transfrontalier intégré (SATI) de l'espace SKBo, Economic and Monetary Union of West Africa (UEMOA) and Swiss Agency for Development and Cooperation, urbaplan, Lausanne,

https://www.urbaplan.ch/wp-content/uploads/2017/07/15068_plaquette_5.pdf.

UEMOA (2017b), Désenclavement du centre de santé de Wanian-Ouarokuy, Economic and Monetary Union of West Africa and Swiss Agency for Development and Cooperation, urbaplan, Lausanne, https://www.urbaplan.ch/wp-content/uploads/2017/07/15068_plaquette_3.pdf.

UNCDF (2017), Annuaire cartographique de l'espace transfrontalier Mali-Burkina-Niger (Espace de l'IIRSahel), Unitied Nations Capital Development Fund's (UNCDF) Local Cross-Border Initiative (LOBI) programme, New York.

UNICEF (2018), Child mortality estimates, www.childmortality.org.

United Nations (2017), World Population Prospects: 2017 Revision, United Nations Population Division

Walther O., A. Howard and D. Retaillé (2015), "West African spatial patterns of economic activities: Combining the 'spatial factor' and 'mobile space' approaches", African Studies Vol. 74 , No. 3, pp. 346-365.

WHO (2017), Atlas of African Health Statistics, World Health Organization, WHO Regional Office for Africa, Brazzaville.

Wismar, M. et al. (eds.) (2011), Cross-border health care in the European Union: Mapping and analysing practices and policies, World Health Organization, Geneva. 


\section{West African Papers}

\section{Businesses and Health in Border Cities}

This report, part of the "Cities" collection, analyses the spatial distribution of formal enterprises and health infrastructure in West Africa. The analysis shows that sectors crucial for regional integration are concentrated in economic capitals rather than in border areas. These results illustrate the difficulty that many West African countries have in distributing the potential for economic development throughout the country. The mapping of health infrastructure shows that border towns have a surplus of medical centres and a deficit of hospitals and maternity wards relative to their urban populations. The report identifies several regions in which closer co-operation could favour the establishment of cross-border health facilities.

\section{OECDpublishing}

